\title{
RUDOLF DVOŘÁK'S STAY IN LEIPZIG AND MUNICH IN THE LIGHT OF CORRESPONDENCE WITH VOJTA NÁPRSTEK: A SELECTION OF DOCUMENTS.
}

\author{
Ondřej Crhák ${ }^{1}$
}

\begin{abstract}
Rudolf Dvořák, one of the founding fathers of Czech Oriental studies, began his academic career as a student at the Faculty of Arts in Prague. In 1882 and 1883 he studied at the University of Leipzig, where he also successfully completed his dissertation. After finishing his studies, he continued his career at the CharlesFerdinand University in Prague. He focused mainly mainly on the Chinese and Middle Eastern regions and translated many texts from these areas. Dvořák's attitudes were under influence of patriotism and nationalism. This mindset, together with a focus on the study of Oriental studies, led Dvořák to Vojta Náprstek, who espoused the ideas of emancipation of the Czech nation and showed an interest in distant lands and cultures. The two men also shared the same attitude to science and scholarship in general. They wished to elevate Czech learning to a competitive level on the world stage and shared strong sense of patriotism. These two intellectuals were in active contact during Dvořák's studies in Germany. Dvořák share his opinions, experiences and attractions from Leipzig and München. In letters he described situation at university and information about its professors. This study brings an edition of these letters.
\end{abstract}

KEYWORDS: Rudolf Dvořák - Orientalist - Oriental studies - Leipzig - Munich college teachers - Leipzig University - Charles University - Vojta Náprstek

Rudolf Dvořák (12 November 1860-1 March 1920) was one of the founding fathers of Czech Oriental studies. He began his academic career as a student at the Faculty of Arts in Prague. In 1882 and 1883 he studied as a scholarship student at the University of Leipzig, where he also successfully completed his dissertation. After finishing his studies, he continued his career at the Faculty of Arts of Charles-Ferdinand University in Prague. The culmination of his work in Prague was his position as rector of the entire university, which he held from 1915-1916. ${ }^{2}$ His professional focus was mainly on the Chinese and Middle Eastern regions. For example, two of his important books are Čínana Konfucia život a nauka (Life and Teaching of the Chinaman Confucius), and O kulturnim významu Arabu pro Evropu (On the Cultural Importance of Arabs for Europe). ${ }^{3}$ He also studied

1 Contact: Ondřej Crhák, National Museum - Náprstek Museum of Asian, African and American Cultures, Prague, Czech Republic; e-mail: ondrej.crhak@nm.cz. This work was supported by the European Regional Development Fund project 'Creativity and Adaptability as Conditions of the Success of Europe in an Interrelated World' (reg. no.: CZ.02.1.01/0.0/0.0/16_019/0000734).

2 Lomová 2020a, p. 26.

3 Dvořák 1887; Dvořák 1887-1889. 
the Quranic texts from linguistic perspective. ${ }^{4}$ In addition to his professional activities, he was involved in translations of Arabic and Turkish poetry, ${ }^{5}$ on which he collaborated with Jaroslav Vrchlický. ${ }^{6}$ As a university professor he was among the founders of Czech Oriental studies as well as of Czech Egyptology and Assyriology. He supported key figures in these fields, such as František Lexa or Bedřich Hrozný. In addition to his work at the university, he was also a member of the Royal Bohemian Society of Sciences and, since 1914, general secretary of Emperor Franz Joseph's Czech Academy for Science, Literature and Art. ${ }^{8}$ In addition to his activities within the academia, Dvořák was in 1892-1898 the editor-in-chief in the production of Ottũv slovník naučný (Otto's encyclopedia) $)^{9}$, to which he contributed a whole series of orientalist entries. ${ }^{10}$

Dvořák's studies are well documented in the Leipzig University's archives records and Charles University's archives; particularly also in Dvořák's collected documents archived by the Czech Academy of Sciences. However, these materials predominantly contain information on the formal course of his studies, i.e., the subjects he studied and his results. Documents from the Náprstek Museum's archives, especially Vojta Náprstek's personal fund, thus provide an interesting complement to the aforementioned sources. This article presents letters sent by Rudolf Dvořák to his friend Náprstek in Prague over the course of his stay in Leipzig and Munich. The total number of letters stored in the archive is twenty-two, but most of them were written after Dvořák's graduation. The presented edition contains ten letters written from abroad in the 1882-1886 period.

The documents presented here help to map out the period of Rudolf Dvořák's studies, but they also provide insights into the thoughts of the young Oriental scholar himself and some segments of the Czech intellectual elite. Dvořák's observations of the different backgrounds of students and scholars at the Leipzig University indicate that contemporary academia, like today, was transnational in nature. They also reveal the close connection between Austria-Hungary and Germany. Many Austrian civil officials studied Oriental studies in Germany as part of their service and thus took a local view of colonial affairs. ${ }^{11}$ On the other hand, the connection also sheds light on the differences, since in Leipzig, tolerance for other nationalities was considerably higher. Dvořák's own work stood rather apart from the general discourse, which

4 Ein Beitrag zur Frage über die Fremdwörter im Korân (A contribution to the question about foreign words in the Quran) Münster, 1884; Über die Fremdwörter im Korân. (About the foreign words in the Quran) 1885.

5 He translated Turkish poems from Bákí and poems in Arabic from Abu Firas al-Hamdani.

6 Jaroslav Vrchlický (1853-1912) was Czech poet and writer.

7 František Lexa (1876-1960) was Czech Egyptologist and founder of Czech Egyptology. Bedřich Hrozný (1879-1952) was a Czech orientalist and linguist, who contributed to the decipherment of the ancient Hittite language; Lexa was he the first Czech scholar to translate and publish ancient Egyptian texts in Czech language; Krumphanzlová 2001; Bareš 2020, pp. 89-91.

8 Dvořák remained in office of general secretary after the fall of the monarchy in 1918; Lomová 2020a, pp. 32-33.

9 Ottưv slovník naučný (Otto's encyclopedia) is the largest encyclopedia written in Czech which was originally created in 1888-1909. The editing of an encyclopedia in Czech language was part of Czech National Revival movement (Cultural movement during the 18th and 19th centuries whose purpose it was to revive the Czech language, culture, and national identity).

10 Lomová 2020a, pp. 40-41.

11 This was essentially a transfer of ideas inside the German cultural sphere. A transposition of ideas associated with colonialism and German Orientalism can thus be considered likely (for more details on the character of German imperialism and colonialism see Marchand 2013, pp. 335-339). 
perhaps reflected Fleischer's influences and his advocacy of 'pure scholarship'. At the same time, Dvořák's personal experience and the importance of nationalism in his time influenced his views of the Orient in a specific way, leading him to see analogies to the Czech struggle for national emancipation. For example, he tried to approximate Turkish culture with translations of Turkish patriotic poetry, and he tried to point out the parallels between Turkish and Czech patriotism. ${ }^{12}$ From the other point of view, Dvořák's letters also illustrate the ideas permeating the world of Vojta Náprstek especially his interest in nationalist issues.

The second half of the $19^{\text {th }}$ century was a time of rising nationalism, national consciousness, and patriotism in the Czech lands. These trends have affected the environment of the Czech intellectual, cultural, and political elites. It is not surprising that nationalism and patriotism also appeared in the mindset and attitudes of Rudolf Dvořák. ${ }^{13}$ These views, together with a focus on the study of Oriental studies, led Dvořák to Vojta Náprstek, who espoused the ideas of emancipation of the Czech nation and showed an interest in distant lands and cultures. Nárpstek was supporter of social modernization and strongly promoted the emancipation of women. The museum, which Náprstek originally built as an industrial museum to exhibit modern technology in the Czech lands, became a meeting place for intellectuals, scientists, artists, and travelers. Náprstek's frequent meetings with Czech travelers led to a gradual transformation of the industrial museum into an ethnographic one. As an admirer of distant lands and especially China, Vojta Náprstek often took liking in persons such as Rudolf Dvořák. In general, Náprstek was interested in young intellectuals who were Czech patriots and their field of interest aimed outside of Europe. It was Náprstek who convinced young Dvořák, who was passionate about his studies of Semitic philology and other languages and cultures of the Middle East, to focus attention on China. Náprstek also supported the young scholar by lending and donating Orientalist literature. On many occasions, Náprstek provided access to his entire vast library. ${ }^{14}$ The two men also shared the same attitude to science and scholarship in general. They wished to elevate Czech learning to a competitive level on the world stage and shared strong sense of patriotism typical of contemporary nationalist movements. In this regard, both men advocated Czech national emancipation, at the very least in terms of cultural achievement. ${ }^{15}$ Naturally, Rudolf Dvořák joined the society formed around Náprstek and his museum, which enabled him to maintain relationships with travellers, as well as the broader cultural and intellectual elite. ${ }^{16}$ In addition to active contact with Náprstek, Dvořák assisted him in editing Chinese publications in the museum library and in transcribing the Chinese language. ${ }^{17}$

During his successful studies at the Faculty of Arts in Prague, Rudolf Dvořák managed to obtain Austrian state grant for a scholarship at Leipzig University. The choice of the university was not accidental as Leipzig University was one of the most important centres of Oriental studies at the time, with Vienna being the only

12 Lomová 2020b, pp. 158-159; Malečková 2020, p. 152.

13 Lomová 2020a, p. 41.

14 Lomová 2020b, p. 158

15 Lomová 2020a, p. 18.

16 Secká 2011, pp. 218-222.

17 Šolle 1994, p. 181. 
competitive alternative in Central Europe. ${ }^{18}$ Leipzig University was home to Professor Heinrich Leberech Fleischer ${ }^{19}$, the de facto founder of what is known as the Leipzig School. In Fleischer's approach, Oriental studies were undoubtedly a sub-discipline of philology. ${ }^{20}$ This understanding of Oriental studies was also reflected in Fleischer's students and, naturally, also in Dvořák himself. Leipzig influenced Dvořák in terms of his connections to world scholarship, as well as his methodological approaches. ${ }^{21}$ Dvořák's studies in Leipzig left such a mark in his professional opinions that the emphasis he put on philology sometimes conflicted with the approaches of the younger generation of Czech scholars, who tended to incorporate other disciplines focused more on the material culture. ${ }^{22}$

Aside from Professor Fleischer, who supervised Dvořák's dissertation, Leipzig University also hosted Christoph $\mathrm{Kreh}^{23}$, scholar of Arabic, and the sinologist Georg von der Gabelentz ${ }^{24}$. The latter became Dvořák's mentor in the study of China and influenced his scholarly pursuits. ${ }^{25}$ Dvořák mentioned his teachers in his letters, too. For instance, in the letter dated to 1 November 1882, Dvořák described Fleischer as a friendly and sprightly gentleman. The fact that Fleischer had a lot of "positive energy' and cared deeply about his students is confirmed in Fleischer's obituary written by another Oriental scholar, Andreas H. Thobercke. ${ }^{26}$ As shown by Dvořák's study records and information from the correspondence below, he was a talented, diligent, and loyal student. Aside from meetings with colleagues in the field, he ceased all other leisurely pursuits and devoted himself to his studies. He mentioned being very busy in his correspondence with Náprstek when apologising for late answers. Dvořák was also likely considered a promising student by his teachers. When Dvořák's stay was nearing its end due to the scholarship expiring, he tried to negotiate an extension with the Austrian government. Professors Fleischer and Krehl

18 Hüsemann 2020, p. 47.

19 Heinrich Leberech Fleischer (1801-1888) was a German Oriental scholar, who studied theology and Oriental languages at Leipzig University and the University of Paris. His main fields of specialization were the Arabic and Persian languages. His main published works include the edition of Historia anteIslamica by Abu al-Fida (F.Chr. Guil. Vogel, 1831), The Golden Necklace by Al-Zamakhshari. Leipzig, 1835 and Commentaries on the Quran by al-Baydawi. Leipzig: Vogel, 1846-1848. Fleischer was also a member of the French Académie des inscriptions et belles-lettres; Fück 1961.

20 Hüsemann 2020, p. 52.

21 Hüsemann 2020, p. 62.

22 This is how prof. Olga Lomová from Faculty of Arts Charles University explained Dvořák's hypercritical attitude manifested in his arguments against the habilitation of another Czech Oriental scholar, Justin Václav Prášek; Lomová 2020a, p. 28.

23 Christoph Ludolf Ehrenfried Krehl (1825-1901) was a German Oriental scholar, who studied and subsequently lectured at Leipzig University. Krehl was one of H. L. Fleischer's students. His main area of study was Islam; Sellheim 1980.

24 Georg von der Gabelentz (1840-1893) was a German linguist and sinologist. He studied at the University of Jena before moving to Leipzig. He is best known for his work on Chinese grammar Chinesische Grammatik: Mit Ausschluss des niederen Stiles und der heutigen Umgangssprache. Leipzig: T.O. Weigel, 1881. Gabelentz was among the most important figures of German Oriental studies; Böttger 1964.

25 Lomová 2020n, p. 160.

26 Hüsemann 2020, p. 55. Andreas Heinrich Thorbecke (1837-1890) was a German Oriental scholar and a specialist on Bedouin poetry. He was one of H. L. Fleischer's students; Merx 1894. 
made the case for Dvořák, but to no avail. Consequently, Dvořák moved to Munich, most likely for financial reasons. ${ }^{27}$

Dvořák's Munich stay in 1883 was not linked to any official study position or teaching appointment at the local university; he stayed there to assist Professor Ernest Trumpp ${ }^{28}$, who was already very ill at the time. Nevertheless, Dvoŕák privately continued his studies and he even informally substituted for professor Trumpp at his seminars. In March 1884, Dvořák graduated in Leipzig and returned to Prague. ${ }^{29}$

The letters illustrate the influence of the social climate prevalent in the Czech lands in the latter half of the $19^{\text {th }}$ century. The issue of Czech nationalism and the relations between Czechs and Germans was a frequently discussed topic. Dvořák observed that the situation in Prague was far tenser among the two nationalities compared to Leipzig. His letters generally indicate that the atmosphere in Leipzig academic circles was friendly and egalitarian. Professors frequently attended the students' informal events and often helped them in their studies by giving access to their private libraries. For instance, von der Gabelentz would let students study in his own apartment. Matters of nationalism and politics were not discussed in local Oriental studies circles. Nevertheless, these issues were part of Dvořák's life. Aside from the fact that he made no secret of his Czech background, he also insisted that the name of his native village - Dřiteñ - be written in its Czech, not German form, on his university diploma. ${ }^{30}$ The different approaches to Czech national sensibilities in Prague and Leipzig are also evident in documents concerning Dvořák from the university in Prague, which consistently tense to his native municipality by its German form Zürnau only. ${ }^{31}$

During the time spent in Germany, Dvořák always actively sought out Czech expatriates and their organisations and reported his findings and experiences in this field to Náprstek. He was especially interested in news about Bohemia in local press and mentions in foreign-language literature. In Leipzig, he frequently attended events organized by the Václav (St. Wenceslaus) association of (mostly) local Czech residents and students. The association's events were predominantly cultural in character. For example, the association staged Czech theatrical plays on New Year's Eve. Dvořák's letters also mention another association - the Slavisch-akademischer Verein. According to Dvořák, the association was dominated by Russians, who were generally quite well represented at the university. In Munich, on the other hand, Dvořák mentioned the existence of a Slavic association and several fellow countrymen, but his letters suggest he was not very active in this regard. Dvořák's experience may, at first glance, be influenced by contemporary Pan-Slavic ethos, although Dvořák himself did not subscribe to Pan-Slavism. In his search for fellow countrymen and reports on nationrelated issues, he systematically mentioned members of other Slavic nations, with

27 Hüsemann 2020, p. 60-61.

28 Ernest Trumpp (1828-1885) was a German professor of Oriental Languages at the University of Munich and a philologist. His work was focused on Persia and India. His publications include Grammar of the Sindhi Language (London, 1872) and Die Religion der Sikhs (Berlin, 1881); Hommel 1894. Dvořák assisted him with translation of some Old Egyptian texts. For example, Dvořák's surviving writings include an undated manuscript containing a translation of Cyril of Alexandria; MUA, Rudolf Dvořák, c. 7, Id. No. 209.

29 Lomová 2020a, p. 21.

30 Lomova 2020a, p. 21.

31 See Dvořák's matriculation diploma; MÚA AV ČR, Rudolf Dvořák, c. 1, Id. No. 3. 
whom he often maintained active contact. Dvořák frequently spoke about Slavs in general in his expressions. However, there is also the human factor: Dvořák found himself a student in a foreign country and he naturally looked for the company of people from culturally close backgrounds. Moreover, there were not that many Czechs among the students in Leipzig and Munich. Czech diaspora in these cities was not sizable either, usually comprising only several hundred families His motivations could also include professional philological interests since Dvořák also attended university courses concerning Slavic languages.

Dvořák's letters also broach social and financial issues. He mentions the material well-being of some of the professors and their students, which he often considered inadequate. This contrasted with the importance assigned to Oriental studies by the German and Austrian governments, which provided students and often offered work to graduates. ${ }^{32}$ Dvořák also mentions this phenomenon in his letter of 22 December 1882, where he discusses the life stories of Gabelentz's students. Dvořák found out that Oriental studies was not a field where one could get rich, also when he was assisting professor Trumpp in Munich, and he also had financial troubles himself. He was forced to delay his graduation until early 1884 . Even though his dissertation thesis was complete, and he had successfully passed the examen rigorosum (doctoral examination), he could not officially graduate in 1883 because he lacked the funds to publish the text in book form right away. Indeed, Dvořák struggled financially his entire life. High travel costs could have been the reason why he never personally visited the places he wrote about. ${ }^{33}$ His correspondence includes references to his accommodations in Leipzig; Dvořák was quite satisfied and noted that he was paying fifteen marks in rent for a twowindow room.

Contemporary Oriental studies were a rather minor field and Dvořák noted the small number of students attending lectures in Leipzig. For instance, a course on Turkey was attended only by himself and another fellow student. Attendance was in single digits in other courses, too. A small number of students in Oriental studies was nothing out of the ordinary as Dvorák found out throughout his scholarly career in Prague. It must be pointed out that Dvorák continued to lecture at the university although he rose through the ranks of the university administration. ${ }^{34}$

32 Marchand 2013, p. 340.

33 Lomová 2020a, pp. 21-22.

34 Dvořák served as dean of the Faculty of Arts from 1900 to 1901 and as rector of the university from 1915 to 1916; Lomová 2020a, p. 28. 


\section{[1] NM-NPM, Vojta Náprstek, c. 168, Id. No. 168.}

\section{Lipsku 1/XI 82 \\ Velectěný Pane!}

Hodlaje slibu dostáti, píši již dnes. Mnoho není toho ovšem, leč snad i to nebude bez zajímavosti, pozdější doba pak poskytne látky více. Po nepřijemné, téměř 12 hodin, trvající cestě noční přibyl jsem v 7 hod do Lipska neznaje nikoho a nikomu neznám. Ponechal jsem věci své na nádraží a šel jsem obhlédnout se po městě pršelo (sic!). Asi o 9 hodině šel jsem do university, i obdržel jsem tam vykázaný byt u universitního pedella Strausse v Paulinum č. 20, lidí to dle úsudku prof. Krehla velmi hodných, bydlím tedy v samé universitě a sice sám mám dosti prostranný pokoj o 2 oknech s vyhlídkou na ulici a platím $15 \mathrm{~m}$.

Ten den odbývalo se právě volba rektora - veliká to slavnost zde i pro veřejnost, tak že i obchody byly uzavřeny - i měl jsem tudíž dosti času město si prohlédnouti. Pověděti bych ovšem nemohl o něm nic více, ba ani ne tolik, leč co poskytují knihy průvodní a proto raději chci pomlčeti. Dnes ve středu byl jsem se představiti $\mathrm{u}$ jednotlivých professorů a byl jsem již v několika přednáškách. Poměry mne mohu říci překvapily. Slýchal jsem o Lipsku co sídle orientálních studií a hle nejvýtečnější orientalista naší doby má v turecké přednášce jednoho posluchače, který jest $\mathrm{k}$ tomu začátečník a mne. Na perštině jsme tři a pouze na arabštině asi 8, každý z jiného národa. Jeden polský Němec, Norvežan, Švýcar, lužický Srb, ostatních neznám posud a já Čech. Profesor Ebers prý pravidelně nečte, jak se mi řeklo a prof. Gabelentz řekl mi při mém představení se, že nemá ani jediného posluchače na čínštinu! Nicméně řekl mi, že počet nerozhoduje a že můžeme pracovati spolu. To bude mi tím vítanějším. Gabelentz je člověk velmi př́ijemný, jaře vypadající a hrozně dlouhý. Když stál vedle mne, převyšoval mne aspoň o dvě hlavy! Snad vyrovnal by se měrou míre Vašeho Čínana. Dojem učinil na mne týž jako v Praze prof. Ludwig - učeného ale přitom roztržitého filologa, který bohužel přednášeti nedovede. Myslím přednes slovný, ne věcný. Tázal se mne, odkud jsem a za jakým účelem jsem přišel, i byl potěšen náramně a podotkl bych stát se apoštolem čínštiny v Praze. Též Čechy prý zná, řekl mi, že studoval čínštinu před časem. Z ostatních professorů byl jsem dosud u Fleischera a Krehla. Fleischer je stařičký člověk menší postavy, náramně přívětivý a velmi rozmarný. Vzpomněl si ihned na dr. Košuta a litoval ho. Prof. Krehl pak přijal mne taktéž s nelíčenou srdečností, ptal se mne však nejprve, jak se vysloví mé jméno a co znamená háček na ř i zkoušel se hned na výslovnosti. To zavedlo jej ihned $\mathrm{k}$ malé přednášce o jotacismu přičemž se zvláštní zálibou dotýkal se ruského měkkého l, kterému se byl v několika slovech za posledního pobytu svého v Rusku od ruského sluhy naučil. To jsou dosavadní mé zkušenosti a povím-li ještě, že jel jsem ve vagoně s obchodníkem, který se mne zčista jasna zeptá: Pane, Vy jste kožišník? - nevím proč - vyčerpal jsem úplně vše, co mohu prozatím psáti. Vzkazuje službu svou pí. choti, Vám, sl. Kláře a všem jsem Váš oddaný Rudolf Dvořák

\section{Translation:}

\section{Leipzig, 1 November 1882}

Dear Sir!

As I wish to stay true to my word, I am writing to you already today. Alas, there is not that much to write about, although I trust my letter will be of some interest to 
you. I hope that some more intriguing subjects will present themselves later. After a tiresome 12-hour-long overnight journey, I arrived at Leipzig at 7 o'clock, knowing nobody and having no acquaintances there. I left my belongings at the railway station and went on to look around the city on foot. Around 9 o'clock, I arrived at the university. The university's beadle, Mr. Strauss, assigned lodgings to me situated in Paulinum No. 20; I will be living with people who, in Prof. Krehl's reckoning, are very kind. Therefore, I will be staying within the university itself where I have been provided with a quite spacious room with two windows and a view of the street for a rent of 15 marks.

On that day, the election of the rector took place, which in this city is a cause for celebration among the townsfolk, too. Hence, shops were closed, and I had plenty of time to see the sights. I would lie if I said that I could tell you more - or even as much - about Leipzig as guidebooks could, so I will write no more. Today, on Wednesday, I went to introduce myself to the professors and I already attended a couple of lectures. I must admit I am surprised by the conditions here. I always heard about Leipzig as the centre of Oriental studies, yet the most excellent Oriental scholar of our age had only a single student attending his lecture on Turkey; that is besides me, of course. At the Persian lecture, there were only three of us and eight students attended the lecture on Arabic, each of a different nationality: a Polish scholar, one Norwegian, a Swiss, one Lusatian Sorb, and I as a Czech. I do not know the others, yet. I have been informed that Professor Ebers ${ }^{35}$ does not hold regular lectures and Prof. Gabelentz told me during our introductions that he had not a single listener in his class on Chinese! Nevertheless, he assured me that the head count does not matter and we could work together. This will be all the better for me. Gabelentz is a very pleasant man, vivacious and terribly tall. He stood two heads taller than me! Perhaps he would stand as tall as your Chinaman. He left me with the same impression as Prof. Ludwig ${ }^{36}$ in Prague - as a learned, but absent-minded philologist who sadly cannot conduct a lecture well. I mean the manner in which he speaks, not the contents. He asked me whence I came and for what purpose; he was very pleased to learn that I would become an apostle of Chinese philology in Prague. He said he knew Bohemia and that he studied Chinese some time ago. Of the other professors, I only visited Fleischer and Krehl so far. Fleischer is an elderly gentleman of a smaller stature who is very friendly and humorous. He immediately remembered Dr. Košut ${ }^{37}$ and pitied him. Prof. Krehl, too, welcomed me with genuine warmth; but first he asked about the pronunciation of my name and what the caron in ' $\mathrm{R}^{\prime}$ meant and immediately tried to pronounce it. This promptly led him to go on a small lecture on iotacism, where he especially fondly talked about the soft ' $\mathrm{L}$ ' sound in Russian, which he had learnt to pronounce in a couple of words from his Russian butler during his

35 Georg Moritz Ebers (1837-1898) was a German Egyptologist and novelist; Richter 1959.

36 Alfred Ludwig (1832-1912) was Czech-German Sanskritist and comparative linguist; Krupa, et al. 1999.

37 Jaromír Břetislav Košut (1854-1880) was a student of H. L. Fleischer at Leipzig University. After returning to his country, he was appointed assistant professor at the university in Prague where he gave lectures on Middle Eastern philology and Islamic studies. Rudolf Dvořák was one of his students and after his death, he published Košut's translation of Hafez's poetry: Háfiz. Jeho život a jeho básně (Hafez: A life and Poetry), Prague 1881; Z dívánu Háfize (From Hafez's Divan), translated with Jaroslav Vrchlický, afterword and explanatory notes by Rudolf Dvořák, Prague 1881; Krupa, et al. 1999. 
previous stay in Russia. This has been my experience so far. I should mention one more thing. I travelled in the railway carriage with a tradesman who, out of the blue, asked me: 'Mister, are you a furrier?' I have no idea why he would do that, and this is all I have to write about. Please give my regards to your lady wife, yourself, and Miss Klára. I remain yours sincerely,

Rudolf Dvořák 


\section{[2] NM-NPM, Vojta Náprstek, c. 168, Id. No. 169}

\section{Lipsku 22/XII 82 \\ Velectěný Pane!}

Odpovídaje na milý dopis Váš ze dne 18. t. m. dnes, první to den našich prázdnin zdejších, musím vysloviti Vám především svůj nelíčený dík za laskavost Vaši, s kterou nabízíte mi pohostinství v domě svém pro nejbližší svátky Vánoční, leč zároveň své politování, že není mi právě možno laskavosti Vaší použiti. Přál bych si ovšem i sám podívat se opět na naši matičku Prahu, leč přilišné zaměstnání nedovoluje mi na ten čas z Lipska se vzdáliti. Pracuji právě na thematu svém, jehož co dissertace doktorské a později snad i své habilitační práce použiti hodlám, i shledávám v prázdninách právě nastalých vhodnou dobu, bych ničím nejsa vyrušován, svému studiu úplně mohl se oddati, v němž jinak v době přednášek (mám 26 hodin týdne) návštěvou koleje dosti citelně jsem vytrhován. Přijmete tedy toto, prosím, mou omluvou nepsal-li jsem dlouho, prosím promiňte i to nebyla to (sic!) liknavost neb zapomenutí, nebylo to také zaneprázdnění - nebo i při sebe věcí práci zbude mi čas k dopisu - leč bylo to jednak pravidlo opatrnosti, jež kázalo mi vyčkati dojem, jaký dopis můj učiní, jednak pak také nedostatek látky, jaký se u mne jevil. Nyní odpadnou snad důvody oba, slibuji, pokud Vás věc bude zajímati, zprávy o sobě častější. Jsou tomu pomalu již dva měsíce, co zdržuji se v Lipsku. Během té doby přivykl jsem zde úplně i vžil jsem se tou měrou v poměry zdejší, že nepřipadá mi ani, že jsem v cizině. Společnosti ovšem nevyhledávám nezbývat' mi k tomu času při zaměstnání mém a o noviny zdejší se nestarám - nezajímajít mne. Tím ovšem nabyl život můj rázu jednotvárnosti a odloučenosti, která však nezdá se mi nijak fádní, studiu mému pak jest zajisté jen ku prospěchu. Jedinými společníky mými jsou mi moji collegové orientalisté s nimiž snáším se, přes rozdil národnosti a snad i smýšlení, co nejlépe, i musím přiznati, že jest mi společnost jich nejvýš milá. $\mathrm{S}$ nimi scházím se denně $\mathrm{v}$ koleji, $\mathrm{v}$ sobotu pak míváme $\mathrm{z}$ pravidla uzavřenou schůzi orientalistů, k níž časem i některý z professorů (mladších) zavítá, což ovšem nijak nevadí nenucenosti zábavy a k utužení vzájemné příchylnosti mezi námi a professory nemálo přispívá. Vủbec zaujímají zde professoři dle mého náhledu a pozorování jiné stanovisko, než jakému jsem já v Praze uvykl, ovšem myslím stanovisko pro obě strany příznivé. Professoři mívají časté přednášky ve studentských spolcích, po přednáškách pak setrvají ve středu studentstva přispívajíce sami všemožně $k$ zábavě. Politika a národnost je ovšem naprosto vyloučena, takže možná jest zde zábava nejlepší tam, kde jevily by se na př́ípad v Praze kontrasty nejkřiklavější.

Pozoruji to nejlépe sám při sobě nebo jakkoli Každý z kollegů ví, že jsem Čech, čímž se nikde netajím, a jakkoli mnozí z kolegů nosí čapky buršácké to v Praze nemožné - panuje mezi námi poměr a zábava nejsrdečnější. Prahu a Čechy vưbec považují ovšem za české - ne jak hlásají Němci v Praze - i stalo se mi, že když jsem se byl představit u prof. Delitsche (assyrologa) a řekl jsem, že jsem Čech z Prahy, řekl mi on Aber wie kommt sie sprechen ja ganz reine Deutsch - a jako jeví se poměr professorů k posluchačům, kde setkají se na místě zábavy, nemíně srdečný jest i kde setkají se v koleji. Vůbec nepřipadá mi poměr ten ani poměrem představeného k níže stojícímu, nýbrž spíše jako poměr rovného k rovnému, ovšem bez zadání své hodnosti. Professoři přicházejí nám vstříc vždy a ve všem s nejvěčí laskavostí a úslužností, nabízejí nám vlastní knihovny k užívání, půjčují nám knihy své domů, a u prof. Gabelentze můžeme pracovat kdykoli v jeho bytu a s jeho knihami. Co se týče studií orientálních na zdejší 
universitě, netěší se ovšem velké oblibě, i překvapily mne. Němci sami, vyjímaje teology, již tvoří zde nejsilnější fakultu a částečně Orientaliemi obírati se musí, jsou při Orientáliích výjimkou, valná věčina orientalistů jsou cizinci z končin nejvzdálenějších a všech národností, jíž přicházejí sem poslechnouti prof. Fleischera, tohoto šeicha, jak jest jeho officiální název mezi orientalisty. Tvoří některá kollegia velmi zajímavý obrázek národností, tak zvláště bezplatné kollegium prof. Fleischera o koránu, kde bývá nás v poslední době někdy až 15 . Je zde New-Yorčan, jistá (sic!) starý profesor (jak si Dává říkati) ze Spojených států, dva Finové (jeden z nich zná se též s docentem Hjärne smluvil jsem se s ním o něm), jeden Švéd, dva Francouzové švýcarští atd. Prof. Gabelentz má 3 posluchače (jistého Rusa, Švýcarského Francouze a mne). Přednáší čtyry hodiny týdně čínštinu a 1 hod Mandžu. Dvě hodiny pak máme u něho v bytu týdně praktické cvičení v čínštině (ve psaní), které promění se občas v zábavné soirée, při němž jak prof. Gabelentz sám tak jeho panička, rodilá Slezanka, a jak se nám přiznala, náruživá milovnice ruštiny, svou vlídností a zábavností se vyznamenávají. U prof. Gabelentze nalezli jsme také na dveřích naznačenou velikost onoho Číňana, jehož velikost máte i Vy poznamenánu, a míru prof. Gabelentze, obě neliší se ani o úplnou píd'. V koleji pokračujeme statně. Své gramatiky zapůjčil nám prof. Gabelentz všem, ve přednáškách pak diktuje nám krátký výtah. Během ledna budeme s gramatikou hotovi a přejdeme k lektuře. Mně líbí se čínština náramně, i neshledávám ji v nejmenší míre obtížnou. Kladet jediný požadavek na pamět́ a logické myšlení, což bohudík u mě obé dosti dobře jest zastoupeno. Přál bych si jenom, by zbývalo mi více času bych mohl jí se obírati. Při svém studiu však mohu se jí zanášeti pouze z hodiny na hodinu. Nicméně i tu pokračuji dosti statně, a prof. Gabelentz nemůže se vynadiviti mé znalosti čínských radikálio. Sám přikročil jsem nyní privátně k lektuře první čínské knihy: San shi king ve vydání St. Juliena, kterou studuji s nejvěčí důkladností právě. Pak hodlám vzíti téhož Tsien tsi ven, načež přejdu k lektuře Shi-kingu. Doufám, že to i při skromném mém času půjde, a až se mi trochu uvolní v mé vlastní práci, což bude bohda ve druhém běhu, hodlám obrátiti se se vším úsilím k čínštině. S prof. Gabelentzem mluvil jsem také o jeho žácích. Dověděl jsem se, že vychoval si posud čtyři sinology. Jeden z nich je habilitován co docent východoasijských jazyků na zdejší universitě, privatisuje ale, maje jmění, v Petrohradě - dr. Grube. Druhý - dr. Uhle - je zaměstnán při knihovně v Drážd'anech, nedaře se mu prý dobře, leč, jest prý očekávati, a jednalo se již o to, že zrrídí se v Německu třetí stolice sinologie, a ta ho asi pak nemine. Třetí Dr. Merz, jest nyní právník a připravuje se ku službě státní. On a čtvrtý žák Gabelentzův - Rheindorf (oba znám osobně) hodlají se vydati v přǐším roce ve službě vlády německé do Číny. Tolik dověděl jsem se o jeho žácích. Též o prof. Pfizmaierovi jsem se smluvil. Řekl mi, že jest to velmi dobrý znatel čínštiny, že ale musí nyní pracovat pro existenci, a to vadí jeho činnosti. Měl prý kdysi dům, ale vedl prý také nákladný život. V domě jeho bydlel prý lahůdkář, od něhož on bral věci, o účet se nestaraje. Jednoho dne přišel lahůdkář s účtem Rovnajícím se ceně domu, a poněvač Pfizmaier nemohl platiti, vzal si jeho dům. Tak prý je on informován. Mně daří se dobře i v koleji i jinak. Mezi Orientalisty zdejšími jsem bez odporu nejlepší, i uznává se to, jak profesory, tak i kollegy mými. U prof. Fleischera vykládal jsem např. v perštině krátce po svém př́ijezdu sem, i pravil mi po přečtení jednoho gazetu Háfizova: Aber sie lesen hübsch, sie werden Wol viel mit Persern gesprochen haben (sic!). A stěží mohl tomu uvěřiti, když jsem řekl, že jsem vủbec nemluvil. A podobně dobře daří se mi i u ostatních professorů. Draho zde není, pouze taky universitní a kolejné stojí mnoho. Immatrikulace stála mne 21 m (v Praze 3 zl) 
a kolejné za 14 hodin placených (ostatní mám publika) $103 \mathrm{~m}$. Včera byl jsem poprvé ve zdejším spolku slovanském: Slavisch-akademischer Verein. Nalezl jsem tam také Čecha - Vaňáska, je učitel i poslán jest rakouskou vládou do cizozemska na studium pedagogiky. Ve spolku jsou převahou Rusové, a proto je jednací řeč a zčásti i zábava ruská. Spolek Václav hodlám navštívit o těchto svátcích. Tím vyčerpal jsem zprávy své a nahradil dlouhým dopisem své mlčení. Prose pak ještě jednou by omluvil Jste mi, že nemohu přijati tentokráte Vaši laskavost' a přeje veselé svátky a štastný nový rok zůstávám s pozdravem srdečným vždycky Váš

Rudolf Dvořák

\section{Translation:}

Leipzig, 22 December 1882

Dear Sir!

I am responding to your heart-warming letter of the $18^{\text {th }}$ of this month. Today, on the first day of local holidays, I must thank you very much for your kind offer to stay in your home during the upcoming Christmas; alas, I will not be in the position to accept your generous invitation. I would very much like to visit our hometown Prague, but sadly my work here does not allow me to leave Leipzig at this moment. I am now working on the theme of my thesis, which I plan on using for my doctoral dissertation and, consequently, perchance also my habilitation thesis. These holidays provide me with an excellent opportunity to fully devote myself to my studies, free of significant distractions commonly afflicting me during lectures (26 hours each week) when I have to attend college. Therefore, I humbly ask you to accept my apology for such a late reply; this was not a result of my hesitancy or forgetfulness, or even business - one should always find some time to write a letter, regardless of the work to be done. I wanted to wait for the impressions my letter would leave and gather more topics to write about. I hope that both reasons will now cease to apply, and I promise that, should you be interested in the subject, I will write more often about my business here. It has been nearly two months since I arrived in Leipzig. During this time, I accustomed myself to the local environment and I no longer even perceive it as foreign. I am not socialising much as I lack the time due to my work and neither do I read the local newspapers, which are of no interest to me. This, however, led my life to become one of seclusion and monotony; yet I do not find it drab and my studies here certainly do benefit. My only companions are my fellow Oriental scholars, with whom I have the best relations despite our differences in nationality and perhaps also persuasion; I have to admit I find their company quite pleasant. I meet them regularly in college and on Saturdays, we usually hold a closed meeting of Oriental scholars; sometimes some of the (younger) professors join us, which nevertheless does not affect the familiar atmosphere and it contributes to the strengthening of bonds between ourselves and the professors. Generally, I must say that professors here have a different attitude from what I became accustomed to in Prague, one that is beneficial to both parties. Professors often hold lectures in student associations and afterwards, they remain with the students, themselves contributing generously to the entertainment. Politics and nationality are not subjects for discussion, which enables us to enjoy occasions which in Prague would show glaring contrasts.

I perceive it firsthand as our relationship and friendship is cordial even though each and every one of my colleagues knows that I am a Czech, which I keep no secrets about, and despite many of my colleagues wearing the Burschenschaften (fraternity) caps. This 
would be quite impossible in Prague. They even consider Prague and Bohemia to be Czech in nature, in contrast to the Germans in Prague. It so happened to me that when I was introducing myself to Prof. Delitzsch (an assyriologist) ${ }^{38}$ and said I am a Czech from Prague, he told me: 'Aber wie kommt sie sprechen ja ganz reine Deutsch' [But how is it that you speak German this perfectly?]. And the attitude of professors to students, when they meet for entertainment, is very cordial, just as when they meet in college. Their attitude towards students does not resemble that of a superior towards a subordinate; they approach students as equals without prejudice to rank. Professors are very helpful and kind to us in all matters, they offer to make their private libraries available to us, lend us books for home study and, in the case of Prof. Gabelentz, one may even work with his books in his very apartment at any time. As concerns Oriental studies at the local university, they do not seem to attract many people, which came as a surprise to me. Germans are rare among students, except for theologians who have the largest faculty here and are required to take up some Oriental subjects. Most students here are foreigners from all manners of distant lands and nationalities, who come to listen to Prof. Fleischer, or the 'sheikh' as is his official title among Oriental scholars. Some collegia make quite a picture of nationalities, especially Prof. Fleischer's free collegium on the Quran, where up to 15 of us were in the audience lately. There is a New Yorker, an old professor (as he wants himself to be called), from the United States, two Finns (one of them knows the assistant professor Hjärne and we talked about him), one Swede, two French speakers from Switzerland etc. Prof. Gabelentz has three students (one Russian, a French-speaking Swiss and me). He teaches Chinese four hours a week, and Manchu for one hour. We also get two hours of practical exercise in Chinese (writing), which sometimes turn into something of an entertaining soirée, where both Prof. Gabelentz and his wife, a native of Silesia and, as she herself admitted, a passionate lover of Russian, provide a friendly and amusing company. Prof. Gabelentz's flat also has the height of the Chinaman you yourself mentioned; he has it marked on the door next to Prof. Gabelentz's own size - they come within less than an inch of each other. We continue stalwartly in the college. Prof. Gabelentz has lent his grammar books to everyone and he dictates brief extracts at his lectures. During January we should complete the grammar and move to reading. I must say I like Chinese a lot and I do not find it hard at all. It is demanding in terms of one's memory and logical thinking, with which I am thankfully adequately endowed. My only wish is to have more time to pursue it. However, with my other studies I can only devote several hours to it. Even then my progress here is quite good and Prof. Gabelentz often marvels at my knowledge of Chinese radicals. I have privately also begun reading my first Chinese book: San Shi King as published by St. Julien ${ }^{39}$, which I am now studying with the utmost diligence. Then I plan on taking up Tsien Tsi Ven from the same ${ }^{40}$, followed

38 Friedrich Conrad Gerhard Delitzsch (1850-1922) was a German Assyriologist. He became a full professor at Leipzig (1885), afterwards serving as a professor at the Universities of Breslau (1893) and Berlin (1899); Littmann 1957.

39 It was the following book: Julien, Stanislas. San-tseu-king: Le Livre de phrases de trois mots en hinois et en franc,ais, suivi d'un grand commentaire, traduit du chinois et d'un petit dictionnaire chinois-français du San-Tseu-King et du Livre des mille mots, par Stanislas Julien; Deux traductions du San-Tseu-King et de son commentaire. Genève: H. Georg, 1873.

The current standard transliteration is Qianzi wen. 
up by the reading of Shi-King ${ }^{41}$. I hope I will manage with the time I have. When I free up some more time in my own work, which hopefully will happen in the second part of the semester, I plan on investing a significant effort in Chinese. I have also talked with Prof. Gabelentz about his students. I learnt that he had managed to educate four sinologists so far. One of them - Dr. Grube ${ }^{42}$ - has been habilitated as assistant professor of East Asian languages at this university, but he is wealthy and is now privately staying in St. Petersburg. The second one - Dr. Uhle ${ }^{43}$ - is employed by the library in Dresden. He is allegedly not doing too well, but if a new seat of sinology were to be established in Germany, which is expected at some point, he is certain to end up there. The third Dr. Merz - is now a lawyer preparing for State service. He and the fourth of Gabelentz's students, Rheindorf (I know both of them personally) plan on going to China in service to the German Government next year. This is what I have learnt about his students. I have also talked with Prof. Gabelentz about Prof. Pfizmaier ${ }^{44}$. I was told he was an expert on Chinese, but now has to work for a living which inhibits his scholarship. He used to have a house somewhere but led quite an expensive life. A delicatessen owner reputedly lived in his house and Pfizmaier liked to order things from him, ignoring the state of his finances. One day, the delicatessen owner came to him with a bill equal to the price of the house, and since Pfizmaier did not have the money to pay, he lost the house. This is what Prof. Gabelentz had heard. I am doing well in college, as well as otherwise. Among the local Oriental scholars, I am without contest the best: both the professors and my colleagues admit as much. Upon my arrival, for instance, I spoke in Persian; after reading one Hafiz's gazette, Prof. Fleischer told me: 'Aber sie lesen hübsch, sie werden Wol viel mit Persern gesprochen haben' [You read good, indeed. You must have talked with Persians a lot]. He could hardly believe me when I told him I had never spoken it before. I have had similar success with the other professors, too. It is not expensive here, only the university and college fees are costly. Matriculation costed me 21 marks (compared to 3 guldens in Prague) and the college fee for 14 paid hours (others are public) was 103 marks. Yesterday, I visited the local Slavic association for the first time: the Slavisch-akademischer Verein. I have also met a Czech man there - certain Vaňásek, who is a teacher sent by the Austrian government abroad to study pedagogy. The association is dominated by Russians and Russian is thus the language of the meetings and partly also of the entertainment. I am planning on visiting the Václav [Wenceslaus] association this holiday. This completes the news I have gathered, replacing my silence with a long letter. I again beg your forgiveness for not being able to accept your kind invitation and wishing you Merry Christmas and Happy New Year, I remain sincerely yours,

Rudolf Dvořák

41 The current standard transliteration is Shi Jing (Book of Songs).

42 Wilhelm Grube (1855-1908) was a German sinologist and ethnographer; Stange 1966.

43 Friedrich Max Uhle (1856-1944) was a German archaeologist who focused on South America territory; Riese 2016.

44 August Philipp Pfizmaier (1808-1887) was an Austrian Oriental scholar focusing on Japan and China; he also studied the Middle East; Linhart 2001. 


\section{[3] NM-NPM, Vojta Náprstek, c. 168, Id. No. 170.}

\section{Lipsko, 29/XII 82}

Velectěný Pane!

Zásilku Vaši obdržel jsem dne 26 t. m., i byl jsem Jí svátečně mile překvapen. Bylat’ mi novým důkazem přízně Vaší ke mně. Přijměte za to, jakož i za Vaše přání ku svátkům mé nejvřelejší díky. Mně nastává ovšem povinnost', hodným se prokázati této přízně a důvěry Vaší. Já chci se o to pokusiti dle sil svých, podaří-li se mi to a pokud zato ovšem ručiti nemohu.

Zásilkou Vaší upamatoval jsem se, že i já mám Vám něco zaslati. Jest to kožený pytel na nohy, Který zapůjčil Jste mi laskavě na mou cestu do Lipska. Když přijel jsem do Lipska, neznal Jsem ovšem poměry zdejší, a měl jsem mimoto tolik svého chození, že nemohl jsem věc ihned obstarati. Odevzdal jsem ji tedy paní, u níž bydlím, k uchování. Později však zapomněl jsem nato docela. Přiznávám se k své chybě úplně, nemoha ji omluviti vyjma chybou samou, zapomenutím, ale stalo se tak zcela proti mé vůli a proto odpust́te.

Od posledního dopisu mého nenaskytlo se mi ovšem nic zvláštního, co mohl bych Vám sděliti, vyjma snad to, že poznal jsem opět o několik lidí více. Především jsou to známí Vám zajisté Poláci dr. Hanušz a p. Przeszinski, jež poznal jsem na prostřední svátek při zábavě zdejšího Spolku českého Václava. Smluvil jsem se nimi, i pravili mi, že byli před počátkem zimního semestru v Praze a i u Vás. Konají zde, co poslanci vlády rakouské studia za podobným účelem jako já, prvý v lingvistice, druhý ve filosofii. Dále seznal jsem slováckého Theologa Kmetě, který slyšel mne prý kdesi česky mluvit, a na základě toho sám se mi představil. Jest to člověk velmi sympathický. I připadá mi sám pravým obrazem zubožené Slovače. dal jsem si od něho leccos vyprávět o poměrech na Slovači, zvláště však zajímalo Mne jeho vypravování o tom, jak Mad'aři Slovákům školy jich zatvořili a jak slovácké studenty pronásledují. Od něho dověděl jsem se též, že studují zde mimo něj ještě dva Slováci, jež však posud neznám. Celkem jest na zdejší universitě dle schematismu 37 Rakušanů.

Na prostřední svátek navštívil jsem zdejší Spolek český „Václav“. Měl právě svůj vánoční stromek a zábavu. Spolek mne skutečně překvapil. Octlt' jsem se zde ve společnosti asi sto osob čítající - snad i více - a sice s výjimkou několika hostí německých, živlu českému př́iznivých, zcela české. Zábava byla velmi nenucená a poměr jednotlivců nejvýš srdečný, takže dojem celkový, jejž spolek na mne učinil musím zváti nejvýš příznivý. Podrobnosti o spolku ovšem neznám posud, ale doufám, že seznámím se s nimi brzy - 8/I. Mají valnou hromadu - i neopominu pak pokud Vás věc bude zajímat, spolehlivý a důkladný obraz o spolku Vám podati. Předběžně dověděl jsem se, že zastoupeno jest ve spolku asi 80 (?) rodin českých zdejších, část pak Čechů, že žije posud mimo spolek. Sám pak mohl jsem pozorovati, že jest to společnost dosti slušná, třeba různí živlové v ní se soustředili. Předsedou spolku jest p. Chadim, bývalý dozorce Fysiologického ústavu prof. Čermáka zde nyní v penzi. Paní jeho je Pražanka, i zná prý velmi dobře rodinu pana Jaromíra Košuta. Celkem jest prý zde asi 500 Slovanů, jichž seznam úplný právě jistý Polák chystá do tisku. Na Silvestra hrají české divadlo. Mně utekly svátky dosti slastně a vesele. Když právě měl jsem pochvíli, procházel jsem se s kolegy městem i hledali jsme Heimatlose rovné nám, i bylo jich hojně. Úterkem počíná nám opět knihovna opětuji svůj dík za zásilku a za prosbu prominutí mého zapomenutí. Přeje pak nového roku znamenám se Vám a všem právě 
přinesla mi paní zpět zásilku na Vás. Pro nával přijímají se na počtě pouze zásilky novoroční a věci nejnutnější. Musím tudíž ještě posečkati.

$\mathrm{S}$ úctou veškerou

R. Dvořák

\section{Translation:}

Leipzig, 29 December 1882

Dear Sir!

I received the consignment on the $26^{\text {th }}$ of this month and was festively and pleasantly surprised. It is another excellent display of your good will towards me. I want to convey my warmest gratitude to you for the package and your holiday wishes. Indeed, this lays on me the responsibility to return your favour and trust. I plan to do my utmost to meet the expectations, yet I cannot guarantee success.

Your consignment reminded me that I, too, should send something to you. It is the leather foot bag you graciously lent me for my journey to Leipzig. When I arrived in Leipzig, I did not know how things worked around here and I also had so many errands that I did not have the time to immediately arrange the matter. Therefore, I handed it over to my landlady. Later I forgot about it completely. I fully admit my failure here since I cannot offer any excuse but my own forgetfulness; it was completely unintentional on my part and I beg your forgiveness.

Since my last letter, there have been no occurrences worthy of conveying to you in writing, except perhaps meetings with some other people. First of all, the Poles who are certainly known to you, Dr. Hanusz and Mr. Przeszinski, which I met at an event organized by the local St. Wenceslaus association on Saint Stephen's Day. We stroke up a conversation and they told me that they had visited Prague and yourself before the beginning of the winter semester. They study here on the behest of the Austrian government for a similar purpose; the former studies linguistics, the latter philosophy. I further met Mr. Kmet', a Slovak theologian who had heard me speaking Czech somewhere and consequently introduced himself to me. He was a very likable individual. He seems to me a true picture of the misery gripping his native land. I listened to his description of the state of Slovakia, and I was especially interested in his retelling of how the Hungarians had closed their schools and persecute Slovak students. I also learnt that besides himself, there are two other Slovaks studying here; I have not met them yet. According to the list, the local university hosts 37 Austrian nationals.

On Saint Stephen's Day, I visited the local Czech 'St. Wenceslaus' association. There was a Christmas tree there and festivities were ongoing. I was quite surprised by the state of the association. I found myself in a society of approximately one hundred individuals, perhaps more - and besides some Germans sympathetic with the Czech nation, the gathering was exclusively Czech. The festivities were quite informal and the individuals' disposition cordial, so my overall impression from the association was indeed quite favourable. I do not yet know details about the association, but I am hoping I will soon learn more, on 8 November. On that date they will hold a general meeting - if you are interested, I will not neglect to provide you with a full and reliable picture of the association. From what I have tentatively learnt so far, the association's membership comprises about 80 (?) local Czech families; some Czechs living here are not yet registered members. As I could see, the society is quite decent, despite 
various people being concentrated there. The chairman is certain Mr. Chadim, former custodian in Prof. Cermák's Physiological institute, who is spending his retirement here. His wife is from Prague and from what I gathered she is well acquainted with the family of Mr. Jaromír Košut. All in all, there are approximately 500 Slavs living here, the list of which is being prepared by a certain Pole for the purposes of print. They stage Czech theatrical plays on New Year's Eve. For myself, the festive season went by splendidly. When I had the time, I met with colleagues walking around the city looking for Heimatlose [displaced persons] like us, and they were aplenty. On Tuesday, the library opens again. I thank you once more for the consignment and beg your forgiveness for my forgetfulness. Wishing you Happy New Year, I send greetings to you and yours. A lady just brought back my consignment to you; on account of an afflux of mail, the post office only accepts New Year's packages and urgent matters. I will thus have to wait.

Yours faithfully,

R. Dvořák 


\section{[4] Undated. NM-NPM, Vojta Náprstek, c. 168, Id. No. 171.}

\section{Vážený Pane!}

Dlouho neodpovídám na milý dopis Vašnostin. Leč omluvou mojí jest zaměstnání moje. Jsem celý den téměř $\mathrm{v}$ přednáškách neb $\mathrm{v}$ knihovně zaneprázdněn, když pak jsem přece si udělal někdy chvilku prázdnou, bych na dopis Váš odpověděl, tu přišlo vždy něco v to, co vyrušilo mne. A tak odpovídám teprve dnes. Zásilky od Vás obdržel jsem všecky. Přijměte prozatím můj nejsrdečnější dík, pokud nebudu míti příležitost jinak za tuto neobyčejnou laskavost a pozornost Vaši se Vám odsloužiti. Od posledního dopisu mého neudálo se mi nic zvláštního, co by zasloužilo býti uvedeno. Pohybujet́ se život můj neustále v týchž kolejích, z nichž pouze tu a tam mohu vybočiti. Práce mám dosti, snad až mnoho, leč pracuji s chutí tím věčí, čím více pozoruji, že práce má nemíjí se cíle. I doufám, že podaří se mi dospěti výsledků v každém ohledu uspokojivých a čestných.

$\mathrm{V}$ čínštině i Mandžu pokračujeme statně, I budeme během měsíce února s látkou úplně hotovi. V čínštině počali jsme již též s lekturou. Čteme Tai Ki tu 太極圖ve vydání A překladu prof. Gabelentze. Lektura poněkud nepohodlná, ježto pohybuje se na poli filosofie, tím více snad možno zní se naučiti. Mně aspoň se líbí, jako vưbec zajímá mne čínština, čím dále ji poznávám, tím věčí měrou, i těším se na tu dobu, kdy bude mi lze více času jí věnovati, než jest mi nyní možno. Kvưli čínštině a pak assyrštině, kterou také, pokud čas mi dovoluje se zanáším, přál bych si, bych mohl ještě aspoň v zimním semestru roku příštího, ne-li celý rok, zde pobýti. Nebo ve svém vlastním oboru nebudu toho již míti potřebí. Ve druhé polovici ledna odeslal jsem sboru profess.v Praze svou žádost na ministerum a další ponechání stipendia i poukázal jsem hlavně $\mathrm{k}$ těmto dvěma oborům v Rakousku téměř nezastoupeným, čínštině a Assyrštině, kvůli nimž přál bych si delší pobyt zde. Jsem dychtiv výsledku. Mát věc pro mne tím více důležitosti, povážím-li, že při úplně nedostatečných pomůckách, jaké budu míti v Praze ve svém oboru, nebude mi možno v něm tak pracovati, jak bych si přál, a že budu tudíž museti obrátiti hlavní svou pozornost $\mathrm{k}$ materiálu, jenž mi v bohaté Vaší knihovně s Vaším dovolením bude přístupen. z nových svých známostí zde uvádím, že seznámil jsem se $u$ prof. Gabelentze s Japoncem Mirou, medikem, u přiležitosti našich cvičení čínských. Pomáhal právě prof. Gabelentzi luštiti čínský nápis zvonu v otisku zaslaném prof. Gabelentzi z Musea Drážd'anského. Jest to člověk silný, prostřední postavy, a kudrnatých vlasů, zjev to, jak řekl mi professor Gabelentz, v Číně velmi řídký. Mluví dosti slušnou němčinou, jíž přiučil se prý za rok. Ostatně je nepřekonatelný hráč ve hře Go, v níž marně prof. Gabelentz zkoušívá s ním při jeho návštěvách své štěstí. Nosí se zcela po evropsku. Mimo něho potkávám zde časem jiného mladíka v čínském kroji s hrozným copem, podle všeho také posluchače university, ač jinak

jsem se o něm posud ničeho nemohl dověděti. Zajímati bude Vás snad také zpráva, že měli jsme při poslední návštěvě krále saského zde také jeho návštěvu u prof. Krehla v Syrštině. Prof. Krehl byl před krátkou dobou jmenován tajným radou, a s tím, aspoň se praví, byla návštěva ta ve spojení. Měli jsme čísti odstavec o dobytí Jerusalema Saladinem ze syrské chroniky Barhebraeovy. Leč vzhledem k tomu, že měla by věc pro hosty naše málo zajímavosti, změnil prof. Krehl lekturu v zajímavou pro nás přednášku o literatuře syrské. Než nepodařilo se mu přece upoutati pozornost královu, který jakkoli celou hodinu v přednášce zůstal, přece čas od času na hodinky se díval a patrně se nebavil. Pouze když nahodilo se prof. Krehlovi něco Syrským písmem psáti, 
tu zaplesalo srdce všech přítomných i vypukli v srdečný smích spojený s podivením nad písmem tím. Jakoby neměly orientalie vyjma svých muřích noh jiné povšechné zajímavosti! A když již píši o samých orientaliích, tedy ještě jednu věc, která zajisté svou kuriositou Vaši pozornost bude poutati. V Beirutě vychází právě Daîret-ul-maârif, (Encyklopedie vědomostî́) od Butrusa (Petra) Bustâniho (Zahradníka). Jest to zcela slovník naučný, folio, tištěný ve dvou sloupcích, sestavený na zprávách vlašských, francouzských, snad německých atd. Dílo bude velmi rozsáhlé; jet' posud u písmeny T (třetí písmě arabské abecedy) a má Již 6. dílů silných. Pokud mohu souditi, jest posud v Evropě jediný exemplar, který obdržel prof. Fleischer od autora darem zaslaný. Dílo vyniká důkladností, tak obsahuje, jak sdělil nám prof. Flesicher celou řadu saských básníků středověku, pro orient zajisté zcela bez významu. U prof. Fleischera míváme každé úterý od 6 - 1/2 9 arabskou společnost, kde přinese nám, co mu napadne, a to pak čteme. Tak otevřeli jsme předposlední hodinu na zdař Bůh slovník ten, a četli život Sv. Tomáše Kempenského. Minulou pak hodinu, když došlo opět k lektuře, přinesl mi prof. Fleischer opět toto dílo, bych na zdař bůh otevřel, a št́astnou náhodou otevřel jsem stránku, kde mimo jiné nalezl jsem pod titulem عارب (Baráz v arabské transkripci) s připojeným francouzským Prague dosti obšírný článek o Praze, který tedy jsem četl. Prof. Fleischer divil se té náhodě, i řekl, že mi chtěl sám ten článek již ukázat, že budu mít radost́. článek sám budu hledět při přiležitosti přeložiti, podobně i s všeobecným článkem o Čechách a vůbec se vším, co o nás tam uveřejněno, a zašlu Vám jej. Budet' to zajisté pro každého Čecha zajímavé dověděti se, jak zní prvá zpráva, která se o Češích do orientu dostane. Prozatím pročítá to prof. Fleischer sám, i nechci jej obtěžovati žádáním o zapůjčení. Článek o Praze zdá se, že sestaven dle dat starších. Uvádí se pouze 4 části Prahy (Hradčín, staré, nové Město a Josefov) a jedna universita. Ostatně je důkladný. Výslovně se podotýká, že po česku se jmenuje Praha, zcela zprávně psáno, a že jest hlavní město Čech, také to zcela dobře, pokud v arabštině možno, psáno, ale hned nato, při udávání obyvatelstva a jinde užívá psaní Tsiche, patrně vliv pramenu odkud čerpal. Zmiňuje se o sedmi pahorcích kolem města, uvádí zeměpisnou šiŕku a délku, rozsah (4 kilometry) obvod (4 hodiny), dále udává počet obyvatel dle národností, zmiňuje se o pamětihodnostech (Hradčín podobá se mu svou věžatostí nejvíce městům orientálním, vytýká universitu, dvě techniky, udává počet obou dle národností, podotýká, kolik posluchačů měla universí (sic!) při založení, že měla nejvěčí počet za Husa, kolik nyní, že má 4 fakulty atd. atd. Celkem velmi zajímavý článek.

V dopisu poslední slíbil jsem Vám důkladnější zprávy o Češích zdejších. Mezitím však seznal jsem, že má spolek sám člena zpravodaje do pražských listů, odkud tedy zprávy o spolku zajisté se dovíte. Ponechám si tedy zprávu svou až na později, kdy budu moci něco důkladnějšího podati. Dnes podotýkám pouze, že měl spolek v úterý maškarní věneček ve prospěch "Ústřední Matice“ (výnos posud Neznám), na němž co kuriosita poprvé snad co Lipsko stojí tančena „Beseda“. Nyní dějí se přípravy k nové zábavě ve prospěch českých škol Vídeňských. Zprávu o prof. Pfizmajerovi oznámil jsem Prof. Gabelentzovi. Podivil se, vlastně nevědět, čemu se má spíše diviti, zda této zprávě, či spůsobu, jak mohla zpráva jemu známá vzniknouti, ostatně referoval relata. Právě co píšu toto psaní dostal jsem od prof. Krehla pozvání k obědu na neděli. Pokrok otázky české university naplňuje mne radostí; pozoruji pokrok ten nejvíce v lamentaci zdejších listů, zvláště Leipziger Tagblattu, jež se zvláštní pozorností všímají si pokroků těch, i neopominou nikdy o nich referovati ovšem s komentářem svých jízlivostí. Naštěstí jest to štěkání psa na měsíc. Od nového roku čítám pravidelně též perský týdenník 
"Achter" (Hvězda) v Konstantinopoli vycházející. Tam ovšem se posud o nás nestarají, aspoň nečetl jsem posud praničeho o nás. Tím vyčerpal jsem své novinky a Končím, podotýkaje, že nemám nejmenšího.

Proti tomu, jestli něco, co zajímavého $\mathrm{v}$ mém dopise jest, dostane se ve známost́ Širšímu obecenstvu. Naopak těší mne, lze li v dopisu mém něco takého najíti. A proto račte jednati dle Vašeho dobrozdání. prose ještě, by přijali Jste opětovně můj dík za pozornost Vaši mne věnovanou, jakož byste omluvili mé delší mlčení, znamenám se se srdečným pozdravem

Všem Váš

Rudolf Dvořák

Orientalista

\section{Translation:}

Dear Sir!

I have long neglected to answer your letter. My excuse is that I am very busy at the moment. For most of the day, I am attending lectures or working in the library. When I had a spare moment to reply to your letter, something came about that distracted me. Therefore, I am responding only now. I have received all your consignments. Please accept my heartfelt thanks until I have the opportunity to repay your exceptional kindness and consideration in some other manner. Nothing noteworthy has happened since my last letter. My life continues on the same track from which I may only occasionally deviate. I have plenty, perhaps even too much work, although I pursue it cheerily, observing as my efforts bear fruit. I am hopeful that I will manage to attain satisfactory and honourable results in all respects.

My colleagues and I are continuing stalwartly in Chinese and Manchu and we will complete the subject-matter fully during February. In Chinese, we have already started with the reading. We are studying Tai Ki tu 太極圖 45 published and translated by Prof. Gabelentz. The reading material is not comfortable as it concerns the field of philosophy; all the more opportunity to learn from it, I say. I myself like that it at least, insomuch as I like Chinese in general - the more I know, the more I appreciate the language - and I am looking forward to the time when I have more time to pursue it than I have these days. For Chinese and Assyrian, which I also study when the time allows, I would like to spend at least the next winter semester, or even the whole year, here. In my own field of study, I will no longer have the need. In the second half of January, I sent to the professor's college in Prague my application for the Ministry, asking for a further extension of the scholarship and referring to the fact that the fields of Chinese and Assyrian are almost unrepresented in Austria and, for that reason, I would like to extend my stay here. I am breathlessly anticipating the result. The matter is all the more important to me when I consider that, on account of the insufficient study means for my field available to me in Prague, I will not be able to pursue it as much as I would like and I would have to turn most of my attention to the material contained in your rich library, which you so kindly made available to me. Of my new acquaintances here, I should note that I met with Mira, a medical student from Japan

45 The current standard transliteration is Taiji tu. Gabelentz, Georg von der. Thai-kih-thu, des Tscheu-Tsi Tafel des urprinzipes, mit Tschu-Hi's commentare nach dem Hoh-pih-sing-li. Dresden: Im CommissionsVerlag bei R. V. Zahn, 1876. 
who I met at Prof. Gabelentz's during our common exercises in Chinese. He was helping Prof. Gabelentz decipher a Chinese bell inscription from an imprint sent to the professor by Dresden Museum. He is a sturdy fellow of medium stature and with curly hair which, as Prof. Gabelentz told me, is quite a rare sight in China. He speaks quite passable German which he reportedly learnt within the span of a year. He is also an unmatched player of Go and Prof. Gabelentz often tries his luck against him when he visits, to no avail. Otherwise, he maintains fully European apparel. Aside from him, I sometimes see another young man in Chinese clothes with a terrible braid, apparently also a student at this university, though I have not yet managed to learn anything more about him. You could also be interested in the news that during the recent visit by the King of Saxony, the king also attended Prof. Krehl's lecture on Assyrian. The word is that Prof. Krehl was recently appointed as Geheimrat [privy councillor] and the visit was associated with this matter. We were to read a paragraph on the conquest of Jerusalem by Saladin from Barhebraeus' Chronicon. However, seeing as the subject was rather less interesting to the guests, Prof. Krehl replaced it with a lecture on Syriac literature. He struggled to attract the king's attention; although the king stayed for the entire hour of the lecture, he looked at his watch frequently and was obviously bored. Only when Prof. Krehl needed to write something in the Syriac script did everyone present burst laughing merrily over the amusing letters. As if Orientalia lacked anything interesting besides their scribbles! While I am writing about Orientalia, I should mention one more thing which you will surely find curious and interesting. In Beirut, the Daîret-ulmaârif (Encyclopaedia of Knowledge) by Betrus (Peter) Bustâni (Gardener) is just being published. This is an encyclopaedic dictionary, a folio tome, printed in two columns and based on Vlach, French, and perhaps even German etc., sources. It is likely to be quite comprehensive as it only reached letter $\mathrm{T}$ (the third letter of the Arabic alphabet) so far and it already contains six thick volumes. As far as I can say, there is only one exemplar of it in Europe, which Prof. Fleischer received as a gift from the author. The work is quite thorough, which is evidenced, as Prof. Fleischer told us, by entries on a number of medieval Saxon poets, which are certainly rather irrelevant for the Orient. Each Tuesday from six to half past eight hours, a society of Arabic scholars meets at prof. Fleischer's; everyone brings what they please and then we read. On the last but one meeting, we randomly opened said dictionary and read about the life of St. Thomas von Kempen. On the last meeting, when we again came to the reading, prof. Fleischer brought up the tome again and I randomly opened it up at a page where I found, among other things, the entry عارب (Baraz in Arabic transcription) ${ }^{46}$ with the French name Prague attached, which contained a quite extensive article on Prague which I read out. Prof. Fleischer wondered at the serendipity and told me that he had wanted to show me the article himself to amuse me. I will translate the article as soon as I get the opportunity, probably alongside the general article on Bohemia and indeed everything published there which concerns our nation; I will then send it to you. I should think any Czech would be interested in learning what the first piece of news on the Czechs coming out in the Orient says. The book is now studied by Prof. Fleischer himself and I do not want to bother him with a request that he lend it to me. The article on Prague appears to be based on older information. It only mentions four city parts (Hradčín, Old and New Town, and Josefov) and one university. Otherwise, it is thorough. It expressly mentions

46 The current transliteration is $b a r \bar{a}^{c}$. 
that the Czech name for the city is 'Praha', it correctly states that it is the capital of Bohemia (Čechy) which is also written correctly as far as the Arabic language allows; however, later when referring on the population and in other places, the word is spelled as 'Tsiche', probably based on the source used. It mentions seven hills around the city, notes the latitude and longitude, size (4 kilometres) and circumference (4 hours), and it further indicates the population according to nationalities; mentions the monuments (Hradčín allegedly resembles Oriental cities due to the many spires and towers), and he notes the university and two technical schools, indicating the number of schools by nationalities, mentions how many students the university had upon foundation, that it had most students in time of Hus and how many study there now, that it has four faculties, etc. etc. Altogether a very interesting article.

In my last letter, I promised more detailed information on the local Czechs. In the meanwhile, however, I found that the association itself has a member who reports on its activities to Prague newspapers, where you will surely learn more. I will thus leave my own report for later when I have something more substantial to say. At this point I will mention just that the association held a fancy-dress ball for the benefit of 'Ústřední Matice' [Central Foundation] (I do not know yet how much money was raised), where 'Beseda' was danced as a curiosity, probably for the first time ever since Leipzig was founded. Preparations are currently being made for a new event for the benefit of Czech schools in Vienna. I conveyed the news of Prof. Pfizmaier to Prof. Gabelentz. He wondered, or rather did not know what to wonder at, whether the news itself or the way a piece of news known to him came to be, he referred that matter. As I am writing this letter, I received invitation from Prof. Krehl to come for lunch on Sunday. The progress of the Czech university fills me with joy; I follow it mostly via the lamentations of local newspapers, especially Leipziger Tageblatt ${ }^{47}$, which is especially interested in the progress, albeit it never misses the opportunity to comment on it caustically. Fortunately, it is akin to a dog barking at the moon. From the New Year, I have begun regularly reading the Persian weekly titled 'Achter' (Star), published in Constantinople. That newspaper, however, is not concerned with us, at least I have not read anything at all that would pertain to us. With this, I have exhausted all my news and I shall conclude, noting that I have not the slightest objection if something interesting in my letter becomes known to a wider audience. On the contrary, I would be pleased if something of that nature was found. Therefore, do as you think best. I once more beg that you accept my thanks for your kindness towards me and my apologies for the long silence. I am sending my heartfelt regards and remain sincerely yours,

Rudolf Dvořák

Oriental scholar 


\section{[5] NM-NPM, Vojta Náprstek, c. 168, Id. No. 172.}

\section{Lipsku 6/IV 83.}

Vážený Pane!

V posledním svém dopisu zmínil jsem se Vám o zprávě, jež nalézá se o Čechách a Praze ve Slovníku naučném, který prací arabského učence Petra (Butrusa) Bîstânîho (my bychom řekli Zahradníka) v Beirutě vychází a v 6 posud vyšlých dílech velikost a úpravy našeho slovníka naučného 3 prvé písmeny abecedy arabské obsahuje. $Z$ toho lze souditi na důkladnost jeho. Dnes podávám Vám vše, co nalezl jsem o Čechách v díle 5. obsahujícím písmenu (sic!) B (P.). Jsou to: povšechný článek o Čechách se článkem o českých bratřích, článek o Praze, Budějovicích a Plzni. Již z toho, jakož i po prohlednutí článků samých lze poznati, že jest to spíše nahodilá volba než něco s úmyslem podniknutého, a že dal se autor určovati ve svém počínání zcela tím, co nalezl v knize (snad francouzké [sic!] neb anglické) z které čerpal, knize ne právě nejnovější, a že nad to mnohdy si ani vědom nebyl, co překládá, čiže co překládá, tomu sám nerozuměl. Já podal jsem překlad co nejslovnější připojiv všude psaní originalu, ze kterého snad bude Vám, jest-li by Vás věc zajímala, možno poznat i ze které asi knihy zprávy čerpány. Bude to zajisté zase nějaká známá encyklopedie francouzká (sic!), angl. neb i vlašská. Překlad sám jest dosti obtížný, poněvač jedná se o věci mnohé, o kterých Arabové ponětí nemají (jako v článku o bratřích českých, kde přicházejí části mše svaté atd.), pro které tedy autor musel sám pojmy tvořiti, jež žádný slovník neobsahuje a kde věčinou věc domyslu jest ponechána. Nemalá obtíž je v transkripci jmen, jež mnohdy velmi komicky a až k nepoznání jsou znetvořena, baže, kdo nezná věc, o níž se jedná, stěží by uhodil na to, co tím míněno. Kde byl jsem v pochybnosti naznačil jsem věc otazníkem, jejž dovedete $\mathrm{Vy}$, maje po ruce pomůcky, jichž mně zde naprosto se nedostává, lehce odstraniti. S články samými učiňte zcela libovolně, jak uznáte za dobré. Až budu míti opět trochu času, vydlužím se od prof. Fleischera ponenáhlu i ostatní dilly, a přeložím i to, co v nich o Češích se nalézá. Myslímt', že jest to dosti zajímavé pro nás, poznat, co zvědí orientálové z této prvé knihy snad, jež o nás jim zprávy podává - Díl, ze kterého jsem právě čerpal, obsahuje též obšírnější články o Bulharsku a Polsku. (Článek o Pař́ži obsahuje plných 36 sloupců!) Knize Připojeny jsou ilustrace; lidí, zviŕat, budov, krajinek etc. - Od posledního dopisu mého uplynula již dlouhá doba, nového však se nenaskytlo mnoho. Běh nový počíná 16 dubnem. Professor Gabelentz bude čísti Japonštinu. Budu poslouchat i ji. Počátkem měsíce května vyjde jeho malá mluvnice čínská s překlady a malou lekturou pro začátečníky ve Vídni. Jest již z části tištěna. Z kollegů v čínštině ztratíme ani ne v plných 14 dnech dva, s nichž zmínil jsem se Vám v jednom z prvých dopisů, že hodlají do Číny. Nad očekávání vyřízena věc jich rychle, i odcestují v nejbližších dnech. Závazek jest na 10 let. Než přiučí se čínštině budou co elevové honorováni $2000 \mathrm{M}$. a volným bytem v německém konsulatu v Číně. Na výpravu obdržel každý 1200 M. i cesta zaplacena jim na státní útraty i strava na lodi, mimo to obdrží každý na den ještě $15 \mathrm{M}$. Jest to Dr Merz a st. theol. Rheisndorf. I v ostatních oborech orientalií ztratili jsme mnohého, oni rozběhli se na jiné univerzity, takže zbýváme prozatím co vlastní orientalisti 3. O Jednoho z kollegů usiluje vláda německá dostati za vrchního bibliothekara do Kaira, kde dříve byl Dr Spitta, tuším kollega Dr Grünerta. A snad se to podaří. - Nového očekáváme pro letní semestr Araba Muhammeda Sâlicha (?) z Konstantinopole, který se arabským dopisem svým ohlásil již Fleischerovi. Přijde-li, je ovšem jiná otázka. O svátcích pomáhal jsem 
prof. Fleischerovi pořádati knihovnu, a tu smluvili jsme se náhodou o Aramejcích od jezera Urmia, kteří počátkem školního roku vybrali po Německu a i v Lipsku příspěvky na vykoupení svých spolubratří, které jim Kurdové zajali. Později však byl jim jich podvod dokázán a oni potrestáni. Myslím, že budou to tytéž, již byli u Vás, a kteří v Čechách vybírali na církev a v Němcích, snad nemohouce tak, na zajaté bratry. Z Vídně obdržel jsem vyřízení své žádosti koncem března. Stipendium mé ponecháno mi na letní semestr. - Jakmile mi bude vyplaceno, bych mohl zaplatit taxy, zadám své thema doktorské über die fremdwörter im Korân, s kterým jsem právě hotov, a jež nyní hodlám opisovati.- Ze známých opustil Lipsko ještě Dr. Hanusz, odebrav se na letní semestr do Berlína. Od pana Vaňáska obdržel jsem dopis, se zpravou (sic!) o vzpomínce na mne při př́ležitosti jeho pobytu v Praze. Srdečný dík za ni. Též dík za poslední zásilku novin, za kterou posud jsem se nepoděkoval. Končím s pozdravem všech a s výrazem hluboké úcty

Váš Rudolf Dvořák.

\section{Translation:}

Leipzig, 6 April 1883.

Dear Sir!

In my last letter, I mentioned the information about Bohemia and Prague included in the Encyclopaedic Dictionary by the Arabic scholar Peter (Butrus) Bustânî (Gardener in meaning) published in Beirut in six volumes so far containing entries covering the first three letters of the Arabic alphabet. It documents his thoroughness. In this letter I will convey all that I found about Bohemia in the fifth volume containing entries under letter B (P.). These are: a general article on Bohemia with an article on Czech Brethren, an article on Prague, Budějovice, and Pilsen. The collection of articles itself, as well as a brief look into their contents, show that this is more or less a random selection than something made with a higher purpose. The author let himself be governed completely by the information he found in the book (perhaps French or English) he used as a source; the book clearly is not of recent provenience and the author was often unaware of what he was translating, or he did not understand its significance. My translation attached hereto is as literal as possible and includes writings from the original, which will hopefully allow you, should you be so inclined, to deduce the book from which the information was drawn. It will certainly be some well-known French, English, or perhaps Vlach encyclopaedia. The translation itself was quite difficult since it concerned many things the Arabs are completely ignorant about (as evidenced e.g. by the article on the Czech Brethren in parts dealing with the mass etc.) and the author had to invent his own words which are not found in any dictionary and leave much to the reader's conjecture. Another trouble occurs in the transcription of names, which are often comically mangled beyond all recognition; someone not well-versed in the topic would only hardly recognize who was meant. I added a question mark in each place where I had doubts; with your tools and aids at hand, you will surely be able to easily remedy these complications. Use the articles themselves in any way you wish and think best. When I have more time, I will eventually lend from Prof. Fleischer the other volumes and translate all that pertains to the Czechs. I believe that it will be instructive for us to learn what the Orientals learn from the information about us contained in this first book - the volume I worked with also included more extensive articles on Bulgaria and Poland. (The article on Paris contains full thirty-six columns!) The book 
also contains illustrations of people, animals, buildings, landscapes etc. A long time has passed since my last letter, but not much has happened. Teaching resumes on 16 April. Professor Gabelentz will lecture on Japanese. I will attend, too. At the beginning of May, his new small Chinese grammar with translations and short reading for beginners will be published in Vienna. It has already partly been printed. Within less than a fortnight we are set to lose two of our colleagues who will be departing for China, as I reported in one of my earlier letters. Their journey was arranged faster than expected and they will depart in the coming days. Their engagement is for ten years. While studying Chinese, they will be rewarded with a 2,000 marks stipend and a free apartment at the German consulate in China. For the expedition, each received the grant of 1,200 marks. State expenses as well as meals on the ship will also be covered and they will also get 15 marks per day. The two men are Dr. Merz and st. theol. Rheisnsdorf. - In other Oriental study fields, too, we have lost many who left for other universities, so only three proper Oriental scholars are left. The German government plans on sending one of the colleagues to Cairo as the chief librarian to replace Dr. Spitta, a colleague of Dr. Grünter I believe. Hopefully the plan will come through. - For the summer semester, we are expecting the arrival of Muhammed Sâlich, an Arab from Constantinople, who has announced this to Fleischer in a letter written in Arabic. Whether he truly arrives is another matter altogether. During the holidays, I was helping Prof. Fleischer organize the library. We came upon the topic of the Arameans from around the Lake Urmia, who at the beginning of the school year collected contributions in Germany and Leipzig to ransom their brethren captured by the Kurds. Later, however, it was found that they had lied and were punished. I believe they may be the same ones who visited you and who in Bohemia tried to collect money for a church, and later, in Germany, for their captured brethren, perchance not wanting to use the same trick twice. By the end of March I received from Vienna a reply to my application. It seems I have retained my grant for the summer semester. - A nice it is paid out to me so that I can pay the fees, I will register the topic of my doctoral thesis, Über die Fremdwörter im Korân, which I am now planning on writing. - Of my other acquaintances, Dr. Hanusz has also left Leipzig, moving to Berlin for the summer semester. I received a letter from Mr. Vaňásek with news that I was remembered on the occasion of his stay in Prague. Please accept my heartfelt word of thanks. I also appreciate the recent consignment of newspaper for which I have yet to thank you. Please convey my regards to everyone. Yours sincerely, Rudolf Dvořák 


\section{[6] NM-NPM, Vojta Náprstek, c. 168, Id. No. 173.}

V Lipsku 22/IV 83.

Velectěný Pane!

Ku mnohým jiným projevům, jež dojdou Vás u přiležitosti dnešního dne, přijmete i mé skromné blahopřání k dnešním Svým jmeninám. Kéž zachován Jste dlouhá ještě léta, by i nadále mohl Jste věnovati vzácné sily Své službě národa našeho a milé vlasti naší.

Přijmete prání toto co výraz úcty a náklonnosti neomezené (sic!) od Vám oddaného Rudolfa Dvořáka.

Díky za zaslané. Srdečný pozdrav všem.

\section{Translation:}

Leipzig, 22 April 1883.

Dear Sir!

Please accept, among the many greetings and salutations arriving on this day, also my own humble congratulations to your name day. May you stay with us for many more long years so that you can devote your precious energies to the service to our dear nation and motherland.

Please accept this wish as an expression of my boundless friendship. Your faithfully, Rudolf Dvořák.

Thank you for what was sent. Cordial greetings to all. 


\section{[7] NM-NPM, Vojta Náprstek, c. 168, Id. No. 174.}

Lipsko 2/VII 83.

Velectěný Pane!

Po dlouhé době chápu se opět péra, bych podal zprávu nějakou o sobě. Činím tak ovšem ne bez ostychu, nevěda, jak vysvětliti si mlčení Vašnostino. Nebo od posledního dopisu Vašeho ze dne tuším 24/I. t. roku zaslal jsem po sobě tři dopisy ve lhůtách rozdílných, na žádný však nedostal jsem odpovědi. Věc pak jest mi tím nevysvětlitelnější, an při zásylce (sic!) Vaší po velikonocích dopis od Vás zpředu mi byl oznámen.

Dnes chápu péra, bych podal Vám zprávu o konečném výsledku svých studií. Dne 29. června běžícího roku dokončil jsem svůj doktorát, podrobiv se ve třech po sobě následujících hodinách od 2-5 hodiny rigorosům $\mathrm{z}$ arabštiny (examinator prof. Dr Krehl), čínštiny (prof. Dr von der Gabelentz) a perštiny (prof. Dr Fleischer). Rigorosa své dělal jsem se všeobecným vyznamenáním, obdrže v co celkovou censuru doktoratu svého: summa cum laude nejlepší to stupeň zdejší stupnice. - Divno Vám bude snad, jak přichází čínština mezi předmety (sic!) mé zkušební. Věc vysvětluji Vám ihned tím, že jsem byl vlastně okolnostmi $\mathrm{k}$ tomu donucen. Chtěl jsem dělati pưvodně rigorosa svá: $\mathrm{z}$ arab. peršt. a turečtiny, tedy svého oboru; pro nedostatek však jednoho zkušebního komihsaře (sic!) musil jsem turečtinu vynechati. Měl jsem volbu nesnadnou. Nebo, jakkoliv byl bych mohl vzíti třeba některou z řečí semitských, $\mathrm{z}$ nichž na příklad $\mathrm{v}$ aethiopštině velmi hezky se vyznám, vadil mi v tom týž nedostatek zkušebního komihsaře (sic!). Jet’ zde pouze Fleischer a Krehl. Reč (sic!) některou zásadní neb starou nemohl jsem se odhodlat si obrati, ana byla by vyžadovala u mne studium, jež by mne bylo zdrželo v mém studiu orientalských jazyků. Na radu professora Gabelentze, jenž prý od prvých počátků s nejvěčím uspokojením a zálibou mé pokroky v čínštině, volil jsem tedy čínštinu. Volbou tou nastala mi ovšem nutná potřeba co nejbedlivěji čínštinou se zanášeti, by rozdíl mezi ní a druhými mnou volenými jazyky nebyl přiliš nápadný. Několik posledních měsíců pracoval jsem výhradně v čínštině, i dospěl v theorii tak daleko, že řekl mi Gabelentz zcela veřejně před kollegy v přednášce: Wenn ich nur meine Grammatik so gut kennen würde wie sie! (sic!) Současně četl jsem čínské klasiky, pokud mi čas stačil, i osvojil si slušnou zásobu znamének. Při rigorosu samém obdržel jsem čísti Konfucia: Hiaó Kīng, i překládal jsem plné tři stránky, v celé té části pak přišla mi pouze tři znaménka neznámá. Vủbec dařilo se mi v čínštině znamenitě, a pokud mohu sám souditi, nazval bych, jakkoli i v ostatních jazycích ganz vortrefflich jsem obstál dle úsudku professorů, přece jen svou zkoušku z čínštiny vrcholem svých úspěchů

Vủbec podobná mým rigorosům snad zde nebyla a hned tak nepřijdou. Professoři př́tomní gratulovali mi vesměs hned po zkoušce, a ještě i druhý den v přednáškách. - Nyní pokračuji v lektuře staročínské poesie, z níž hodlám co nejdříve podati ukázky našemu obecenstvu, ač-li setkám se s ochotou u časopisů vašich, které, pokud mohu souditi, považují, posud orientalia za něco, co lid náš nepotřebuje. Tak aspoň se chovají, chtěl-li bych jim něco zaslati.

V nejbližších dnech hodlám zadati svou žádost o ponechání mi stipendia mého i na rok přiští; strávil bych jej zde rád, bych nyní, kdy hotov jsem se svými zkouškami, tím pozorněji se mohl svým studiím věnovati. Na škodu mi to zajisté nebude, i budu si moci aspoň látku nějakou pro práce pozdější sebrati. Za tím účelem zůstanu zde bezpochyby též přes prázdniny, ač-li mi v to nic nepřijde. Bibliotheka universitní bude mi přístupna, jak mi professor Krehl již přislíbil. 
Zároveň chci pracovati v bibliothece zdejší rady městské, která má velkou sbírku rukopisů orientálních. Zvláště interesuje mne nejpřednější lyrik turecký Bâki, posud nevydaný, jejž snad bych pokusil se vydati. Novot a novinek vlastních neznám. Nezbylot́ mi pranic času v poslední době, bych všímal si něčeho jiného než svého studia. Známosti své rozšíril jsem o známost s Japoncem Jijimou, stud. přírodních věd z Tokio (sic!), který mně sám vyhledal s prosbou, bych přeložil mu do němčiny jedno pojednání prof. Vejdovského. Snad použije ho, jak mi řekl, pro japonskou svou práci. Vyhověl jsem ovšem s radostí jeho žádosti.

Zbývá mi ještě oznámiti Vám, že od prvého t. m. bydlím v Querstrahse 21-23 - přízemí. Noviny, jež během doby poslední mi Vámi byly zaslány, obdržel jsem všecky.

Děkuje pak za jich zasláním (sic!), končím dopis svůj, prose, by odpustili Jste, jestli, snad trochu déle zdržel jsem se při vypisování svého doktorátu. Myslím, že jest to věc, která Vás bude zajímati, s druhé strany pak zdá se mi býti důležitou i pro suší knihy, ano jedná se tu snad o čestné representování Čechů v cizině, což doufám se mi podařilo. Se srdečným pozdravem Vám a všem známým jsem

Váš Rudolf Dvořák.

\section{Translation:}

Leipzig, 2 July 1883.

Dear Sir!

Once again, I set my pen to paper to give you some news of myself. I do so with a certain hesitance, oblivious to the reasons behind your prolonged silence. For since your last letter, dated, I believe, the 24 January of this year, I have sent you three different letters at different times, none of which I received an answer to. I am all the more puzzled as in that last consignment of yours after Easter you affirmed that you would write.

Today I set pen to paper to give you word on the final results of my studies. On the 29 June I finished my doctoral studies, having undergone three full consecutive hours from two to five o'clock, an examen rigorosum from Arabic (examining Professor Dr. Krehl), Chinese (Professor Dr. von der Gabelentz), and Persian (Professor Dr. Fleischer). These examinations I have passed with the highest distinction, summa cum laude, or the highest possible attainment here. You may find it perplexing that Chinese was amongst the subjects I have taken for examination. This I shall explain straightaway, having happened by force of circumstance. Originally, I wanted to take the examen rigorosum in Arabic, Persian, and Turkish, these being my own field of studies. But because the examination committee was lacking one examiner, I had to do without Turkish. I thus faced an uneasy decision. For though I could have chosen one of the Semitic languages, such as Aethiopian, which I am reasonably accomplished in, that ambition, too, was thwarted by the aforementioned lack of examiners; there were none available but Fleischer and Krehl. I did not dare to choose one of the classical or ancient languages because it would require studying in a way that would interfere with my own academic focus, Oriental languages. I thus followed the advice of Professor Gabelentz, who claimed to have always observed my progress in Chinese with the utmost satisfaction and picked Chinese. Such a choice, however, created the necessity to pursue Chinese with fastidious deliberation, lest the difference between Chinese and my other chosen languages be particularly striking. Thus, for the past several months, I have worked exclusively on my Chinese and even improved in grammar to the extent that professor Gabelentz gave me public praise in front of colleagues during a lecture, claiming: ‘Wenn 
ich nur meine Grammatik so gut kennen würde wie sie!' (sic!) [If only I knew my grammar as well as you do!]. When time permitted, I also read Chinese classics and acquired the knowledge of a considerable number of characters. During the exam itself, I was supposed to read from the Hiaó King ${ }^{48}$ by Confucius. I translated full three pages and I was unfamiliar with no more than three characters. I excelled at Chinese and if I am bold enough to judge, I would claim the examination in Chinese to be the pinnacle of my achievement, no matter how well and excellent (ganz vortrefflich) I did in the other languages in my professor's eyes.

I have never passed an examination even remotely similar to the examen rigorosum nor will I any time soon. The professors all congratulated me immediately after the examination and in classes on the day after. I am now continuing in reading Old Chinese poetry, of which I intend to present samples to our audience as soon as circumstances allow, provided I meet with interest on the part of your magazines which, I reckon, have not yet considered Orientalia to be something our people need to know about. That is at least how they respond when I offer them something for publishing.

In the coming days, I am planning on sending application for an extension of my grant for the next year; I would very much like to spend it here as having completed my examinations, I could fully devote myself to my studies. It would certainly be of no harm and I could at least collect materials for my future work. For this purpose, too, I will certainly stay here over the holidays if the circumstances allow. The university's library will be made available to me as Professor Krehl has promised.

At the same time, I plan on working in the city library which contains a large collection of Oriental manuscripts. I am especially interested in the foremost Turkish lyrical poet, Bâki, as of yet unpublished, whom I would perhaps try to publish myself. I have no personal news to report. I have had very little spare time lately to spend for something other than my studies. I got acquainted with the Japanese man Jijima, a natural sciences student from Tokyo, who approached me asking whether I could translate a treatise by Prof. Vejdovský into German for him. He told me he would use it in his Japanese work. I gladly granted his request.

It only remains to tell you that from the $1^{\text {st }}$ day of this month, I have moved to Querstrahse No. 21 - 23, the ground floor.

I did receive all the newspapers you have sent me recently.

Thanking you for them I conclude this letter begging your pardon if it took me longer than expected to describe my doctorate. I believe it is a matter that will be of interest to you; on the other hand, it appears important also for drier books; yes, it concerns honourable representation of Czechs abroad, in which I hopefully succeeded. Cordial greetings to you and yours. Your faithfully, Rudolf Dvořák 


\section{[8] NM-NPM, Vojta Náprstek, c. 168, Id. No. 175.}

Mnichov 3/X o 10 hod. dop.

Ctěný Pane.

V úterý ráno odejel jsem z Budějovic i přijel rychlikem Přes Linec a Solnohrad o 6 hod 35. večer zdráv do Mnichova. Přijetí se strany pana prof. Bylo Vřelé. Pan ing. Vašek bydlí v sousedství A maje za ženu Würtemberačku je s prof. Trumppem A jeho paní (oba jsou z Würtemb.) nejen v sousedství nýbrž i v bližší známosti. Od nich zpraven byl již o mém příchodu. Při nejbližší přiležitosti jej navštívím. Ostatní dopisem později. Pozdrav všem. S úctou Váš

Dvořák

Translation:

Munich, 3 October, 10 AM.

Dear Sir,

Tuesday morning, I left Budějovice, taking an express train through Linz and Salzburg, and arrived at Munich healthy and well at 6:35 AM. The professor [Trumpp] gave me a warm welcome. Ing. Vašek lives in the neighbourhood and his wife being from Württemberg, he is well acquainted with Professor Trumpp and his lady wife (who are both from Württemberg as well), who have already passed him word of my arrival. I shall pay him a visit at the earliest opportunity. The rest I shall recount in the following letter.

My regards to everyone. Respectfully yours

Dvořák 


\section{[9] NM-NPM, Vojta Náprstek, c. 168, Id. No. 176.}

Mnichov 8. října 1883

Vážený Pane!

Slíbil jsem odjížděje z Prahy, že budu brzy psáti. Lístek Korespondenční, jímž oznámil jsem Vám svůj štastný př́ijezd do Mnichova, zaslal jsem Vám hned druhý den, i nepochybuji, že Jste jej obdrželi. Dnes jsem téměř Celý týden zde, i mohu Vám podrobnějších zprav osobě podati. Jak známo Vám, odjel jsem v neděli večerním vlakem z Prahy do Budějovic, kam přijel jsem o 1/2 3 hod. ráno. Doma očekával mne již dopis od pí prof. Trumppové, plný obav, že snad nepřijedu, a zároveň slibů, že postarají se o mé pohodlí co nejlépe, tak že bude se mi tam jistě líbiti atd. Napsal jsem tedy ihned dopis, kterým oznámil jsem příchod svůj na 2. řijen večer. Druhý den ráno vyjel jsem pak o $1 \frac{1}{2} 7 \mathrm{z}$ domova a po 12 hodinové nepřetržité jízdě přes Linec a odtud neustále rychlíkem II. třídy, ano jiného spojení přímého nebylo, přes Solnohrady do Mnichova, kam dojeli jsme o $1 / 27$ hodině večerní. Cesta byla mi sice trochu dlouhá, nabývala ale aspoň částečně př́ijemnosti pro mne půvabnou krajinou svou, kterou nám bylo jeti. Zvláště horské řetězi alpské se svými z části sněhem pokrytými velikány, jež viděl jsem poprvé, poutaly mou pozornost v míře svrchované, neméně jezera a řeky.

Mnichově nebyl jsem očekáván, na dopis můj, jejž zaslal jsem dne 1. října, dostal se do Mnichova teprve dne 3. ř́jjna odpoledne, tedy v době, kdy jsem již celý den téměř byl na místě. Zajímavý příklad správnosti o rychlosti našich (či německých) pošt. Nádraží vzdáleno jest dobré půl hodiny od mého bytu, vůkol pak rozestírala se tma. Sedl jsem tedy na tramway, jež dovezla mne až do naší Hörmanstrasse. Zde slezl jsem a na zdař bůh počal hledati svůj budoucí byt. Úloha ta byla pro mne dosti mrzutou, na ulici ta jest jednou z nejnovějších města, z části posud nevystavena, a vyznamenává se ne sice blátivým ale hrubým šterkem navezeným trotoirrem, v němž každou chvíli jsem klopýtal, nad to pak naprostou tmou egyptskou. Nikde svítilna! Na štěstí nebylo domů mnoho, tak že bych je v pádě potřeby byl mohl všecky prohledat, nad to pak jsou číslovány po řadě tak že číslo 5 jest také pátým domem. Tak jsem kombinoval také, a skutečně přišel jsem po krátkém hledání a tápání v temnotě večerní $\mathrm{k}$ domu, na němž jsem dle slabých obrysů písma za pomoci své fantazie vyčetl jméno prof. Trumpp vedle jména lze za dne spatřiti jinou tabulku: vor dem Hunde Wird gewarnt, tu jsem já ale neviděl, a tak stalo se, že když pln radosti, že jsem konečně doma, otevřel jsem ničeho netuše Dvéře, vyřítil se na mne mocný hafan, jako by chtěl mne roztrhati. Na štěstí naháněl strachu pouze štěkotem a dorážením, nejsa jinak nebezpečným a tak prošlo vše bez jakéhokoli neštěstí. rodinu prof. Trumppa nalezl jsem právě shromážděnu $\mathrm{u}$ večeře, $\mathrm{k}$ níž musil jsem ihned, představiv se, zasednouti. Skládá se z 5 kousků, dvou starých a tří mladších ač ne mladých, mezi nimi jedno femininum jak dvacetileté a dvě maskulina studující gymnasium. Rodina jest protestantská: velmi hodná, zcela po domácku zařízená, prostě však hezky, umělecká a učenecká. Otec učenec, matka spisovatelka, dcera malîŕka. Nějaké piano a housle jsou při tom též. Prof. Trumpp, dle data narození 55letník vypadá mnohem stařeji a jest nad míru sešlý a sklíčený. Oko jedno jest slepé, druhé valně zesláblé; k tomu druží se pak jiné nemoci, jež trápí jej ustavičně. Vědomí pak vlastního stavu, jakož i strach, jejž bídu prof. ještě zvěčuje, an spatřuje vše ve světle mnohem horším, činí jej pravým hippochondrem. Při tom jest mu čas velmi dlouhý, an zvyklý jsa vždy studie nyní k ustavičné zahálce jest odsouzen. Jediným jeho zaměstnáním jest řezání dříví, jež mu doktor k vưli věčímu pohybu těla přikázal. 
A tak vše dřiví, jež v domě se spotřebuje, pochází z rukou universitního prof. Ostatně, jak jsem pravil, jest velmi hodný, zkušený a učený člověk. Původně byl duchovním, a co taký poslán byl do Afghanistanu jako misionář, kde strávil celou řadu let. Jazyky tamější zvláště pak perština jsou jeho druhou řečí mateřskou, i mluví jimi úplně plynně. Snad budu moci lečemus se od něho přiučiti. Od mého příchodu slibuje si prý velmi mnoho, a jak mi pí prof. Sdělila, je již nyní v mnohém ohledu zcela změněn. Přednášky odřekl, až na perštinu, kterou bude čísti. Doma budeme spolu pracovati 1-2 hodiny, ačli dovolí mu to jeho stav (posud nemohli jsme pracovati) střídavě v arabštině, perštině a aethiopštině. v posledních dvou řečech má velmi hezkou knihovnu, mimo to slušnou řadu rukopisů, zvláště mnoho cenných foliantů aethiopských. Poslední probírám právě, sestavuje jich katalog, prozatím pro profesora, později snad pro veřejnost. Není to ale práce mi uložená, nýbrž pracuji dobrovolně. Vůbec mám veškerem čas svůj volný, vyjma zmíněnou 1-2 hodiny, které pospolu budeme pracovati. Někdy jdeme též spolu na procházku paní Trumppová jest rovněž nadmíru vzdělaná, uhlazená, při tom ale vší povrchnosti prostá paní.

S mužem svým prodělala celou misii afganskou, i Má bohatou zkušenost za sebou. Cestu svou popsala velmi zajímavým spůsobem ve Stuttgartských Jugendblätter od 1867-1876, zábavně, jinde vědecky. Nadto píše novelly \& Hospodářství vede si sama i obstarává si celou domácnost, již má po venkovsku zařízenu. Chová si slepice, kachny \&\&. Má sice služku, ale jak mi sdělila, pracuje ona a dcera její v domácnosti, právě tak, jako by nikoho neměly, vyjímaje ovšem práce hrubší. Řekla mi, děti své že nechá vzdělati ve všem možném nešetříc nákladu nejvěčího, při tom ale že vychovává je zcela prostě a po domácku, by připraveny na vše vešly někdy do světa. oba jsou, jak jsem již psal, Würtemberáci, i podrželi vedle jiného zajisté i mluvu svou, jež mnohdy velmi hezky se vyjímá. Každé st vyslovují jako št např. er Išt.

A nyní ještě něco o mé domácnosti. Prof. má svůj dům nevelký ale hezký, v němž bydlí sám s rodinou. Nájemníků nemá. K vlastnímu domu jest přistavená část přizemní s vyhlídkou do zahrady, jejíž jediným obyvatelem jsem já. Mám pro sebe dva pokoje, studovnu o dvou oknech s vyhlídkou do zahrady, a spací pokoj o 1 okně s vyhlídkou na dvůr. Zaopatření mám úplné, posluha je jak náleží, i jsem zcela spokojen. Strava je zcela slušná, i jíme všickni v rodině.

Dům nalézá se v nejzdravější části Mnichova, obklopen kol zahradou, jež náleží profesorovi, dále pak lukama, jež snad pozdější doba bude zastavovati. Na blízku jest Englischer Garten se svými procházkami. Dům jest stavba pana Vaška.

O Mnichově samém nemohu mnoho říci, poněvač ho posud neznám. Nadto znáte jej Vy lépe. Pomalu prohlížím si jeho zajímavosti, ze všeho pak soudím, že bude se mi líbiti. Universitu máme asi 10 minut od domu, i můžeme jeti až k ní tramwayí. Zápis počíná 15. Rektorem je dr. Prinz, který byl prý dříve též prof. uni. v Praze. Budu mu též představen Prof. Trumppem. tolik prozatím. Jindy více počasí máme nestálé. Pršky, mlhy, slunce stř́idají Se ustavičně. Jen zima je stále. Dnes viděl jsem prvý led. Je vidět, že jsme v horách. Pana Vaška navštívím co nejdříve. Chtěl jsem již tak učiniti, ale an je přiliš zaměstnán, nelze jej snadno doma najíti. Včera byl jsem též v kavárně Vám známé, kde četl jsem Národní. Nalezl jsem tam jednoho Čecha. Též o spolku Slovanů již vím, i podívám se tam nejblíže. V neděli minulou slavili Svatováclavské posvícení i byli veseli do rána. Pan Vašek též je navštívil. S českým malîrem Rypotou setkal jsem se též. Ostatní českou společnost neznám. 
Tolik prozatím. Děkuje pak za zaslané časopisy znamenám se se srdečným pozdravem na všecky známé Váš

Rudolf Dvořák

NB. Málem byl bych úplně zapomněl, že mám prosbu jakousi k Vám. Ředitel českých chlapeckých škol Budějovických Novotný má dceru Filoménu, zkoušenou učitelku toho času na škole Netolické. Táž žádá o místo na některé škole pražské, v předměstí neb i v Praze samé. Ucházejíc se o místo to, zvěděla, že i Vy mohl byste jí býti pomocným. Mne pak žádala za přímluvu a sprostředkování. Já nemám na věci pražádného interessu a sděluji Vám Věc tu, činím pouze to, zač byl jsem požádán. Pouze tolik Vás mohu ujistiti na základě toho, jak znám celou rodinu onu, že pomoc Vaše nebyla by poskytnuta nehodnému. A proto přimlouval bych se za Vaši podporu, ovšem jen v tom pádu, je-li Vám to možno beze všech obtíží a namáhání. Nebo vím sám, že jste přiliš zaměstnán, než abyste mohl podobnými věcmi se zanášeti. Proto odpust́te.

\section{Translation:}

Munich, 8 October 1883.

Dear Sir,

When leaving Prague, I promised to write soon. I doubt not that you have received the postal card which I sent on the very next day, announcing I have arrived safely in Munich. It has been a week since I arrived and thus, I can share a more detailed account of my impressions. As you know, I took the Sunday evening train from Prague to Budějovice, where I arrived at half past two in the morning. At home I found a letter from Mrs. Trumpp, who was concerned that perhaps I would not come at all, promising to take care of me as best they could so that I certainly would enjoy my stay. Hence, I wrote a letter right away, announcing to arrive on 2 October in the evening. The following day I left home at half past six and, after a 12-hour uninterrupted journey by an express train in the second class - no, there was indeed no other direct connection - via Linz and Salzburg, I arrived in Munich at half past six in the evening. The journey was rather long, but at least made enjoyable by the pretty landscapes that we chanced to pass through. It was the first time that I beheld the mighty mountain range of the Alps, the giant snow-capped peaks; these, in particular, caught my eye, alongside all the rivers and lakes.

I was not expected in Munich, as the letter I sent on 1 October did not reach Munich before 3 October in the afternoon, nearly a whole day after I had arrived. A truly outstanding demonstration of the swiftness of our (or the German) postal service. The railway station was half an hour's walk from my lodgings and the surroundings lay in darkness. I got onto a tram car which brought me as far as our place at Hörmanstrasse. Here I got off and haphazardly set off to seek my future lodgings. It was an onerous task, as the street is one of the newest in the whole town, still unfinished in part and infamous for its course, albeit not muddy gravel trottoir ${ }^{49}$; now and again I was stumbling, ever more so for the pitch-black Egyptian darkness surrounding me. No lantern to be seen! Fortunately, the houses were sparse, so I could look at each of them if I needed to. Moreover, house numbers were placed in sequence, so No. 5 was indeed the fifth house in the row. Thus, I counted the houses

49 Trottoir - from French, pavement. 
and after a brief moment of searching and staggering in the darkness I managed to arrive at the house where I - employing my imagination - deciphered the faint outlines of writing to read the name of Professor Trumpp. What I did not notice was another plate which, looking at it in daylight later, read: 'Vor dem Hunde wird gewarnt' [Beware of the dog]. Overfilled with joy to be home at last, unsuspecting I opened the door, and a mighty dog went for me, as though he would rip me apart. Fortunately, he only barked and snapped at me, not being a particularly dangerous animal; no tragedy thus befell me. I met Professor Trumpp's family at the dinner table, who asked me to join them right after I had introduced myself. The family consists of five members: two older and three youngers, though not quite very young. Among these, there is one female, twenty years of age, and two males who study at a grammar school. The family is Protestant; most kind, artistic and scholarly, their house is homely, plain, yet neat. The father of the family is a scholar, the mother a writer, the daughter a painter. A piano and a violin are to be found there as well. Professor Trumpp, who has seen his $55^{\text {th }}$ winter, seems indeed much older, being worn out and dispirited, blind in one eye, failing eyesight in the other. A few other illnesses harrow him incessantly. Awareness of his physical condition, as well as his fears, only add to the plight of the poor professor; seeing everything in a much darker light makes him a true hypochondriac. He has too much time on his hands; having been used to studying, now he is doomed to permanent idleness. His only pastime is sawing wood, which he is doing to exercise his body at his doctor's command. Hence all the wood used in the house was cut by the hands of a university professor. For that matter, as I said, he is a very kind, experienced and well-read person. Originally, he was a clergyman and as such he had spent several years' time in Afghanistan as a missionary. He is well-spoken in the Afghan languages and Persian in particular, which has become like his second mother tongue. Hopefully, I will be able to learn a lot from him. He is excessively optimistic about my stay, and as his lady wife has let me know, he is quite changed in many aspects. He refused to give further lecture, except for Persian where he would read. We should work together one to two hours a day if his condition allows (we have not been able to work so far) in Arabic, Persian, and Ethiopian. He has collected quite a nice library and a nice collection of manuscripts, especially many valuable Ethiopian tomes. I am right now parsing through them, assembling a catalogue for the professor, but later perchance also for the public. This is a task I have voluntarily assigned to myself, not one given to me. Otherwise, I have lots of spare time except the aforementioned one to two hours I will be working with the professor. Sometimes we go for a walk; Ms. Trumpp is also very educated, polite, and free of any superficiality.

She accompanied her husband during the entire mission in Afghanistan and is herself quite accomplished. From 1867 to 1876, she described the entire journey in a very engaging, yet scholarly manner in Stuttgarter Jugendblätter. She also writes novels and manages the entire household, which is arranged in a rustic fashion. She rears chicken, ducks etc. While she employs a maidservant, as she told me, she and her daughter take care of the house as if they did not, except for more menial work. She explained to me that she will spare no expense to educate her children in all manners of learning, but at the same time she raises them humbly and with knowledge of domestic work so that they are able to take care of themselves when they leave for the wider world. As I wrote earlier, both the professor and his lady wife are from Württemberg, 
retaining among other things their dialect which is often quite pleasant to hear. Each 'st' is pronounced 'sht', for instance.

Now something about the household, I am staying at. The Professor's house is not large, but it is neat, and he lives there with his family. He has no tenants. A ground floor extension has been added to the house itself with a view of the garden, where I am now staying alone. I have at my disposal two rooms, a study with two windows and a view of the garden, and a bedroom with one window and a view of the courtyard. I am served very well, and I am perfectly satisfied. Meals are very good, and we eat them together with the whole family.

The house is situated in the healthiest part of Munich, surrounded by a garden belonging to the Professor, and some meadows which will later see further development, I suppose. The Englischer Garten is close by for walks. The house was built by Mr. Vašek.

I cannot tell you more about the city of Munich itself as I do not know it yet. Moreover, you are probably more familiar with it in any case. I am leisurely examining its landmarks, which lead me to believe I will like it here. The university is about 10 minutes walk from the house, but we can now take the tram there. Matriculation begins on the $15^{\text {th }}$. The rector here is Dr. Prinz, who apparently spent some time as a professor in Prague. I will be introduced to him by Prof. Trumpp. The weather is quite inconstant. Showers, fogs, and sunshine work by spells. It is rather cold. Today I saw the first ice. It shows that we are in the mountains. I will visit Mr. Vašek as soon as possible. I planned on doing so already, but he is very busy and hard to catch at home. Yesterday I also visited the coffee-room which you are familiar with, where I read the Národní [The National newspaper]. I chanced upon a Czech man there. I also already know of the Slavic Association; I will visit it as soon as I can. Last Sunday they celebrated the St. Wenceslaus feast and the merriment lasted till morning. Mr. Vašek attended it, too. I also met with the Czech painter Rypota. The other Czechs I do not know.

That is all I have. Thanking you for the magazines you sent, I am sending my best regards to you and yours. Faithfully,

Rudolf Dvořák

NB (Nota Bene): I nearly forgot that I must beg your help with a certain matter. Novotný, the headmaster of Czech boys' schools in Budějovice, has a daughter named Filoména, who is struggling at the Netolická school. She applies for a place at one of the schools in Prague, either in the outskirts or in Prague proper. While she has sought such a position, she had learnt that you could potentially be of assistance in that objective. Hence, she asked me to intercede on her behalf. As I have no personal interest in the matter, I am merely doing as I have promised. I can only assure you that based on my knowledge of her entire family, your helping hand would not be extended to someone unworthy. Therefore, I would very much appreciate your assistance, but only if it does not cause you too much inconvenience. I am well aware that you are far too busy to occupy yourself with such trifles. I thus beg your pardon. ${ }^{50}$

50 As an active proponent of female education, Vojta Náprstek was a patron of various associations as well as individual students in Prague. For this purpose, he also founded the 'Americký klub dam' (American Ladies Association). Dvořák could not have approached a better person with this request; Secká 2013, pp. 20-22. 


\section{[10] NM-NPM, Vojta Náprstek, c. 168, Id. No. 179.}

Lipsko 18/VII 86.

Vážený Pane!

Štáastně dostal jsem se až do Lipska, kde nyní vězím živ, zdráv a vesel. Bláznivé počasí, jež rovná se jako vejce vejci našemu pražskému sice nepodporovalo by náladu, kdyby si člověk z něho co dělal, za to podporuje ji však laskavé vítání, jakého dostává se mi od mých bývalých profesorů. Chodím zde skorem okolkem na oběd od jednoho ke druhému. I doporučení do Leydenu sami mi nabídli na professory i bibliothekary. Doposud byl jsem u Krehla a Fleischera. Gabelentz ujel mi do Poschwitz v sobotu, i nezbývá mi, chci-li se s ním setkat, než zdržet se proti původnímu úmyslu svému do středy. Nebo v úterý zde již bude. Prozatím zvěděl jsem, že jest Gabelentz deputantem saské vlády pro sjezd orientalistů ve Vídni. Pojede-li tedy Preton, nabídnu mu, by Vás navštívil. Richthoffena navštívím pak současně s Gabelentzem, bydlít v nejbližším sousedství, oba hodně daleko za městem (sic!). Jiného prozatím zváti nemám. Často vzpomínám (sic!) si na Vašeho p. páva, jehož líbezný hlásek připomíná mi každé protivné zapísknutí zdejších lokomotiv.

S pozdravem srdečný Vám, pí Náprstkové a všem pánům a dámám společnosti Vaší Váš Dr. R. Dvořák

Na rozích jsou zde plakáty ohlašující od 24 počínaje 10. výstupu japonské a čínské společnosti nějaké. Škoda, že zde nebudu; ostatně uvidíte je snad i v Praze.

\section{Translation:}

Leipzig, 18 July 1886.

Dear Sir,

I safely arrived in Leipzig where I am now dwelling alive, healthy, and happy. While the capricious weather corresponding one to one to the weather in Prague would not support good spirits if one were to pay it too much heed, I have received the warmest welcome from my former professors. I am now essentially making rounds from one to the other for lunch. They have offered me recommendations for professorships and librarianships in Leyden. So far, I have visited Krehl and Fleischer. I just missed Gabelentz, who went to Poschwitz on Saturday. If I am to meet with him, I will have to prolong my sojourn here until Wednesday as opposed to my previous plans. He is returning on Tuesday. For now, I found out that Gabelentz has been selected as the representative of the Saxon government for the congress of Oriental scholars in Vienna. If Preton should go, then I will offer him to visit you. I will visit Richthofen ${ }^{51}$ simultaneously with Gabelentz as they live in the same neighbourhood, well outside the city. I should not invite anyone else for the time being. I often remember your peacock; of whose lovely voice I am reminded each time the local locomotives blow their annoying whistles.

Please give my regards to yourself Ms. Náprstek and all ladies and gentlemen in your company. Yours faithfully,

Dr R. Dvořák

51 Ferdinand von Richthofen (1833-1905) was a German traveller and geographer; Lindgren 2003. 
There are posters here at corners announcing that from the $24^{\text {th }}$, the $10^{\text {th }}$ performance of some kind of a Japanese and Chinese society will take place. Pity I will not be here to attend; but you will perchance be able to see them in Prague, too. 


\section{Literature:}

Bareš, L. (2020). Organizátor, který otevíral cestu české egyptologii a asyriologii. In: Lomová, O., ed., Ex oriente lux. Praha, pp. 81-98.

Böttger, W. (1964). Gabelentz, Georg von der. In: Neue Deutsche Biographie 6, p. 3.

Dvořák, R. (1884). Ein Beitrag zur Frage über die Fremdwörter im Korân. Münster.

Dvořák, R. (1885). Über die Fremdwörter im Korân.

Dvořák, R. (1887). O kulturním významu Arabi̊ pro Evropu [On the Cultural Importance of Arabs for Europe]. Prague.

Dvořák, R. (1887-1889). Čínana Konfucia život a nauka [Life and Teaching of the Chinaman Confucius]. Prague.

Fück, J.W. (1961). Fleischer, Heinrich Leberecht. In: Neue Deutsche Biographie 5, pp. 231-232.

Hommel, F. (1894). Trumpp, Ernst. In: Allgemeine Deutsche Biographie 38, pp. 687-689.

Hüsemann, J. H. (2020). Na univerzitě v Lipsku. In: Lomová, O., ed., Ex oriente lux. Praha, pp. 47-64.

Krupa, V., Opatrný, J., Kolmaš, J. and Filipský, J. (1999). Košut, Jaromír Břetislav. [online] Database of Czech and Slovak orientalists, Africanists and Ibero-Americanists. Available at: https://www.libri.cz/databaze/orient/search.php?name=kosut [Accessed 10 Sep. 2021].

Krupa, V., Opatrný, J., Kolmaš, J. and Filipský, J. (1999). Ludwig, Alfred. [online] Database of Czech and Slovak orientalists, Africanists and Ibero-Americanists. Available at: https:// www.libri.cz/databaze/orient/search.php?name=Ludwig [Accessed 10 Sep. 2021].

Lindgren, U. (2003). Richthofen, Ferdinand Freiherr von. In: Neue Deutsche Biographie 21, pp. 543-544.

Linhart, S. (2001). Pfizmaier, August. In: Neue Deutsche Biographie 20, p. 345-346.

Littmann, E. (1957). Delitzsch, Friedrich. In: Neue Deutsche Biographie 3, p. 582.

Lomová, O. (2020a). Mezi Orientem a probuzením českého národa. In: Lomová, O., ed., Ex oriente lux. Praha, pp. 13-46.

Lomová, O. (2020b). Studium nejzamilovanjší. In: Lomová, O., ed., Ex oriente lux. Praha, pp. 155-172. 
Malečková, J. (2020). Od klasické "orientální" poezie k turecké národní literatuře. In: Lomová, O., ed., Ex oriente lux. Praha, pp. 135-154.

Marchand, S. (2013). German Orientalism in the Age of Empire: Religion, race and Scholarship. Cambridge.

Merx (1894). Thorbecke, Andreas Heinrich. In: Allgemeine Deutsche Biographie 38, pp. 115-117.

Riese, B. (2016). Uhle, Max. In: Neue Deutsche Biographie 26, pp. 537-539.

Richter, K. (1959). Ebers, Georg. In: Neue Deutsche Biographie 4, pp. 249-250.

Secká, M. (2003). Americký klub dam: krůček k ženské vzdělanosti. Praha.

Secká, M. (2011). Vojta Náprstek: vlatenec, sběratel, mecenáš. Praha.

Sellheim, R. (1980). Krehl, Ludolf. In: Neue Deutsche Biographie 12, pp. 732-733.

Stange, H. (1966). Grube, Wilhelm. In: Neue Deutsche Biographie 7, pp. 175-176.

Šolle, Z. (1994). Vojta Náprstek a jeho doba. Praha.

\section{Archival sources:}

Archive of Náprstek Museum (NM-NpM), personal fond of Vojta Náprstek.

Archive of Czech Academy of Science (MÚA AV ČR), personal fond of Rudolf Dvořák. 